\title{
EL QUIEBRO DEL PSOE EN 1933 (DEL GOBIERNO A LA REVOLUCIÓN) \\ Y II
}

\author{
Víctor Manuel Arbeloa Muru \\ Licenciado en Teología e Historia de la Iglesia \\ Universidad Gregoriana de Roma \\ Licenciado en Filosofía \\ Universidad Complutense de Madrid
}

Sumario. 1. El Gobierno de Martínez Barrio. 2. Ante las elecciones a Cortes. 3. Candidaturas electorales. El fin de la conjunción republicano-socialista. 4. Hacia la Revolución social violenta. 5. Todo el poder para los socialistas. 6. La primera vuelta y sus efectos.

Desde el 9 de septiembre hasta el día 2 de octubre no se abrieron las Cortes. En ésta última fecha presentó don Alejandro su Gobierno al Congreso de los diputados. ${ }^{1}$. Si su declaración programática tuvo un carácter provocador o no, discuten los autores. Lo cierto es que, como venía diciendo desde hacía mucho tiempo fuera de las Cortes, volvió a decir, dentro de ellas, que el Parlamento estaba «divorciado» de la «opinión pública» y que, habiendo cumplido su misión, «se había gastado». No habló de «Parlamento desprestigiado», como le entendieron sus críticos, pero dijo algo muy similar: Ese Parlamento gastado «no tenía ya en la opinión pública la consideración sin la cual el prestigio no acompaña a la autoridad de esta alta corporación». Fue muy crítico con la situación política española, como lo fue en su intervención parlamentaria del 14 de junio, como pudimos ver. Defendió «la democracia de la disciplina, de la jerarquía, de la autoridad» en un país «al borde de la anarquía por la izquierda o al borde de cualquier género de Dictadura por la derecha»; se declaró autonomista, como lo había demostrado cuando el debate del estatuto de Cataluña, y se dolió de ser tachado frecuentemente como anti-autonomista; prometió respetar la obra republicana de los Gobiernos anteriores, incluidas las leyes laicas, si bien en su aplicación había de de poner «la máxima consideración», que ya había anunciado en la asamblea extraordinaria del partido, en octubre de 1932.

Como programa inmediato propuso: dar remate al proyecto de ley sobre arrendamientos rústicos, ya muy avanzado en la Cámara; preparar los presupuestos generales del Estado y votar los créditos indispensables para los fines de la política del Consejo. Para sorpresa de muchos anunció también, «como signo de este cambio en la gobernación del país», y sin más especificación, una próxima amnistía, - punto programático principal del Frente Antimarxista,

${ }^{1}$ Cortes Constituyentes, vol. 10, núm. 404, 2 de octubre de 1933, pp. 4-31. El discurso programático de Lerroux, en pp. 4-12. 
como vimos más arriba-, amnistía que había acordado el Consejo de Ministros por unanimidad, y encomendado al ministro de Justicia, el radical-socialista izquierdista, Juan Botella Asensi, la preparación del proyecto de ley, detalle que Lerroux remachará en su réplica como prueba de su espíritu liberal. La noticia levantó «rumores» en varios sitios del salón de sesiones. El Gobierno declaró arrogantemente don Alejandro al final de su peroración- no se allanará a estar mediatizado por ningún poder de la tierra. Y en seguida, un poco de humor celeste, que causa «fuertes rumores» en algunas bancadas de la Cámara: «Y estaba por deciros que estamos tan alejados de las manos de Dios, que no creo que ningún poder divino intervenga en nuestras causas»».

Veintisiete diputados socialistas, encabezados por Indalecio Prieto, Largo Caballero, Julián Zugazagoitia y Enrique de Francisco, y en cuya lista tampoco falta Fernando de los Ríos, presentan incontinenti un ruego a las Cortes para que se sirvan declarar que el Gobierno nombrado el 12 de septiembre «no tiene su confianza».

No era propiamente un voto de censura, como aclararán después el mismo Prieto y el presidente de las Cortes. Seguidamente el recio orador bilbaíno pronuncia uno de los mejores discursos de su vida: puntilloso, fogoso, implacable ${ }^{2}$. Si el Parlamento está divorciado de la opinión, si está desprestigiado, ¿para qué pedirle su voto, su confianza? Pero lo más nuclear de la pieza oratoria de Prieto es dejar solemnemente claro que la colaboración de los socialistas con los republicanos ha terminado, Y lo dice él, heraldo siempre de la conjunción republicano-socialista. Por cierto, sabían por la prensa que un grupo republicano al menos (¿los radical socialistas de Domingo, la Esquerra?) ponía como condición para entrar en el nuevo gabinete la participación del partido socialista, pero después cambiaron las tornas: «nosotros no fuimos requeridos absolutamente por nadie, y el partido o grupo que había establecido esta condición la suprimió, en uso de su libérrima voluntad». Quede, pues, consignado, en nombre del PSOE, «a efectos históricos»: «que los partidos republicanos, el día 11 de septiembre de 1933, dejaron cancelados con el partido socialista todos los compromisos que a requerimiento de ellos adquirió para instaurar y consolidar la República, y que desde esa fecha somos total, absoluta, plenamente libres».

Manuel Azaña, otro buen orador, más sosegado pero no menos eficaz que su predecesor en la tribuna parlamentaria, defiende antes que todo su intensa tarea gubernamental ${ }^{3}$. Cuenta que el jefe del Estado preguntó a los ministros reunidos en Consejo: «¿Creen ustedes que éste es el mejor Gobierno para presidir unas elecciones?». Se trataba de las futuras elecciones municipales. El presidente del Consejo respondió: «Señor Presidente, la pregunta nos honra, pero no tenemos términos de comparación». Y presentó incontinenti la dimisión de su Gobierno. Accediendo a las preguntas de Prieto acerca de

${ }^{2}$ Ibid., pp. 12-18.

3 Ibid., pp. 18-30. 
la lealtad de los socialistas y de la opinión de Acción Republicana sobre el ministerio Lerroux, donde tienen un ministro, Azaña asegura que jamás ha tenido en sus gabinetes «la menor queja, ni la menor sospecha de falta de lealtad, ni el menor atisbo de que dentro del Gobierno los colaboradores socialistas hicieran otra cosa que el estricto cumplimiento de su deber y la observación de la obligación común que todos nos habíamos impuesto. No nos queda nada por quemar, nada por olvidar, desabrimiento alguno que perdonar».

En cuanto a la posición de AR ante la nueva situación, reconoce que fueron el primer partido en ofrecer al encargado de formarlo su participación: para conservar el Parlamento, y para evitar entre republicanos «un desgarrón difícil de remendar». Viendo luego que se intentaba atraerse sólo a «personalidades», que, además, eran parte de algún partido, se retrajeron de la colaboración ofrecida, y así se lo dijeron a don Niceto. Pero al fin pudieron entenderse directamente con el nuevo presidente del Consejo y aceptaron ir al Gobierno, con tal de que no sustentara doctrina opuesta a la suya y no derogasen las leyes que ellos aprobaron. El anterior presidente del Consejo hace las mismas preguntas que el ex ministro socialista a don Alejandro: ¿para qué quiere consultar a un Parlamento divorciado y desprestigiado? Le interrumpe respetuosamente Lerroux para negar que haya llamado «desprestigiado» al Parlamento, y tiene razón. A don Manuel le basta el epíteto «divorciado» para urdir el tejido sutil de sus apóstrofos y sus retruécanos. Muchas líneas dedica a lo que le parece fundamental: el nuevo candidato intenta, en una maniobra propia de la Monarquía desaparecida, pedir a la Cámara el voto de confianza para luego pedir su disolución. ¡Ese es el «truco» y esa la «farsa»!, grita Prieto, adhiriéndose a la tesis del orador, que expone todo un tratadito sobre la viciada política en torno al decreto de disolución.

Además de juzgar tardía la presentación del nuevo ministerio ante el Congreso, considera «ofuscación deplorable» la crítica sistemática de Lerroux a la obra de los anteriores Gobiernos, por ponerles en la alternativa de tener que elegir entre las Cortes y él mismo, y carga enérgico contra el nuevo banco azul: «Vosotros no sois el Ministerio que las puede disolver». No son el Gobierno que puede y debe ser «común para todos, amparo para todos y seguridad y suelo de imparcialidad para todos». Grandes aplausos. Acción republicana no tiene participación alguna en la declaración ministerial. El docto historiador y catedrático de la universidad complutense, Claudio Sánchez Albornoz, embajador en Buenos Aires, elegido para nuevo ministro de Estado, está todavía llegando en el barco, y el mismo Azaña y otros diputados hacen alguna chanza sobre su embarque y su desembarque. Por supuesto, AR no aportará su voto a la amnistía de «los culpables del 10 de agosto», cuando todavía hay docenas de procesados pendientes de juicio: sería un caso de «corrupción del régimen republicano» y de «desviación de sus fines». ¡Asunto en todo caso de las próximas Cortes! Se renuevan los aplausos. 
Al día siguiente, el portavoz de la Esquerra, Antoni Maria Sbert, con argumentos similares a los de Azaña, retiró en nombre de su grupo a su ministro de cuota, Miguel Santaló ${ }^{-}$-a quien Lerroux elogió luego como ejemplo de lealtad de principio a fin-.y dejó ver que ellos eran partidarios de contar con el partido socialista en el Gobierno Lerroux.

Otro orador de campanillas fue el radical-socialista Félix Gordón Ordás, ya bien conocido nuestro, representante del único grupo, o semigrupo como en este caso, que no negó la confianza a Lerroux, aparte del republicano radical $^{5}$. Crítico, como sabemos, con el Gobierno, especialmente en lo tocante a la reforma agraria, acusó a los socialistas, con quienes colaboró durante un cuarto de siglo en León, de rechazar la colaboración con los republicanos, como hizo patente la declaración de Prieto, y de algo más grave: «Desde el periódico, órgano de del partido, y por boca de algunos de sus hombres más ilustres, hace ya tiempo que se ha venido manifestando que en la República española se ha planteado el problema de elegir entre marxismo y fascismo, y eso, entre nosotros los republicanos, no podemos aceptarlo (Aplausos en la minoría radical); es un disparate que no tiene razón ni fundamento de ser». Y menos cuando desde los ministerios se habla de la lucha de clases dentro de la República. Los suyos votarán a favor del Gobierno, exigiendo, eso sí, el respeto, «en su esencia», a la legislación republicana.

Don Alejandro no era ya «el mejor orador (...) que hay en el parlamento español», como le definió, en el mismos salón de sesiones, en noviembre de 1921, aquel impetuoso periodista vasco, asturiano de origen, convertido en diputado socialista por Bilbao, llamado Indalecio Prieto. Pero el que tuvo retuvo, y el verbo barroco de aquel fascinador de masas en Barcelona y en toda España durante los primeros años del siglo era todavía un verbo impetuoso y para muchos convincente. Era, como se describió a sí mismo en su primera y contemporizadora réplica, un «león viejo», que aún se atrevía con otro «león joven», pero a quien le era imposible luchar con «la serpiente», que era, como lo tradujo sin pelos en la lengua, Manuel Azaña.

El viejo «emperador del Paralelo» pronunció el último discurso de la crisis $^{6}$, comenzando con las célebres palabras: «Señores diputados, los que van a morir os saludan». Fue sobre todo un ajuste de cuentas con Manuel Azaña -hombre «que no tiene corazón», y «hombre que para destruir se pinta solo», como dirá una y otra vez- desde sus comunes trabajos en Alianza Republicana (1926) hasta su último Gobierno, a la vez que una respuesta amarga y decepcionada al discurso del ex presidente del Consejo.

Terminado lo cual, Leroux quiso dar todo por terminado anunciando en la tribuna la presentación de su dimisión al presidente de la República y re-

\footnotetext{
${ }^{4}$ Ibid., núm. 405, 3 de octubre de 1933, pp. 3-5.

5 Ibid., pp. 5-10.

${ }^{6}$ Ibid., pp. 10-14.
} 
tirarse con todos los miembros del Gobierno que aún quedaban Pero el presidente Besteiro, que militó por poco tiempo en su juventud toledana dentro de las huestes radicales, le rogó-obligó, en un tenso diálogo, a permanecer en el salón hasta oír a todos los parlamentarios que habían pedido la palabra y conocer el resultado de la votación sobre la moción presentada.

Prieto, con palabras entre vehementes y cordiales, le insta a evitar la «fuga». Y de pronto interviene Azaña con otro discurso río ${ }^{7[}$, lamentado por él mismo por lo casero y mezquino, respondiendo al último del presidente, que juzga personal y políticamente injusto. Es una breve historia de las relaciones entre republicanos en esos siete años, al que el «moriturus» presidente apenas tiene ya aliento para replicar: Se trata en ambos casos de críticas menudas, reproches personales, desmentidas, excusas, protestas de aprecio y respeto, pequeñas revelaciones, confianza perdida... Nos enteramos, por ejemplo, de que Lerroux declinó la ofrecida presidencia del Consejo, tanto el 15 de octubre como el 2 de diciembre de 1931, no porque hubiese socialistas en el equipo de Gobierno, sino porque tenían carteras demasiado importantes. Triste espectáculo.

Fueron 187 votos a favor de la «no confianza» y sólo 91 en contra, es decir, a favor del nuevo Gobierno de Lerroux. Nada menos que 190 diputados no tomaron parte en la votación. Ni una sola personalidad intelectual de las muchas que poblaban la Cámara se dignó votar: más o menos, como en la votación del 20 de junio. Los diputados radicales, los radical-socialistas de Gordón Ordás y algunos federales fueron los únicos que se opusieron a la no-confianza. Se la negaron los socialistas, Esquerra Republicana, Acción Republicana, los radicalsocialistas de Domingo, los republicanos gallegos, la mayoría de los federales , algunos progresistas, algunos independientes. Agrarios y vasconavarros en bloque estuvieron ausentes También el comunista andaluz por libre, José Antonio Balbontín, votó con la mayoría, al triple grito de «¡Abajo el fascismo! ¡Abajo el socialfascismo! ¡Viva el frente único revolucionario!» ${ }^{8}$.

\section{EL GOBIERNO DE MARTÍNEZ BARRIO.}

Alcalá Zamora volvió a llamar a consultas a los representantes oficiales de los partidos, pero, además, según su áulica costumbre, a personalidades

${ }^{7}$ Ibid., pp. 16-23.

${ }^{8}$ Alejandro Lerroux, en su libro de memorias, expresa en términos muy vivos, su dolor y su tribulación en aquellas horas, pero sin la menor autocrítica: «No se habrá visto caso igual, deslealtad más cínica, traición más descarada, ni ministros más desairados que aquéllos». Todo le pareció una «innoble conjura con todos los caracteres de la más estudiada bellaquería» por parte de quienes le facilitaron todo hasta el final, para después «tumbarle inutilizado». En otro momento confiesa sincero, lo mismo que había hecho en el Congreso: «La serpiente era Azaña, naturalmente». Lerroux, A., La pequeña historia: Apuntes para la historia grande vividos y redactados por el autor, Ed. Cimera, Buenos Aires, 1945, pp. 166-179. 
o viejos políticos como don Miguel, don Gregorio, don Felipe o don Melquíades... Y encargó al fin, sucesivamente, la formación del nuevo Gobierno a dos hijos ilustres de ministros de la Monarquía: primeramente al ya mencionado jurista y catedrático de derecho civil, Felipe Sánchez-Román, diputado independiente por Madrid y defensor de Largo Caballero tras la «revolución de Jaca» en 1930; un santón reconocido entre muchos republicanos de la oposición. Y, en segundo lugar, a quien ni siquiera era diputado: José Manuel Pedregal jurista prestigioso también, ministro de Hacienda en 1921, durante muchos años diputado liberal al Congreso, ex presidente del Consejo de Estado y de la Academia de Ciencias Morales y Políticas, pero sobre todo, y era por lo que el presidente le buscaba, presidente del Patronato de la Institución Libre de Enseñanza.

Aún tuvo humor para apelar a un tercero: al insigne escritor y médico médico de cabecera también de don Niceto- Gregorio Marañón, uno de los fundadores de la Asociación al Servicio de la República (ASR) y entonces diputado independiente por Madrid-capital, que no había abierto la boca en la Cámara. Fue el encargado más activo, que anduvo de zocos en colodros hasta el fracaso final. Y ya, para remate, no sé si para lucirse en la nómina o para consultarle sobre el sentido del artículo 75 de la Constitución, convocó don Niceto al insigne ex catedrático de derecho político en la universal central, jubilado ya en 1931, Adolfo González Posada, discípulo de Giner de los Ríos, ex senador por Oviedo y autor de numerosas obras jurídicas. Los cuatro devolvieron el encargo presidencial. El primero, porque no quería catalanes en el nuevo Gobierno; el segundo, porque fue rechazado por las dos fracciones radical-socialistas, el tercero porque los radicales se negaron a que entraran los socialistas, que era conditio sine qua non para el PRRSI; no conozco los motivos del cuarto, quien tal vez no movió un dedo ni dio un solo paso.

Con la ausencia de Manuel Cordero y la presencia del secretario del grupo parlamentario, José Ruiz del Toro, diputado por la provincia de Murcia, y de Juan Negrín, ya vicepresidente del mismo grupo, diputado por Las Palmas de Gran Canaria, se celebró la reunión de la comisión ejecutiva socialista el día 4 de octubre?.

El presidente Caballero informa sobre la llamada, el día anterior, a palacio por el presidente de la República para evacuar consulta en la crisis planteada en el Parlamento. Confiesa paladinamente los motivos de su negativa: su «imposibilidad de poder asistir a Palacio por estimar que el Partido ha declarado ya su incompatibilidad con la formación de un Gobierno socialista y republicano. En segundo lugar, porque yo estimo que la evacuación de consultas es una cosa de ritual, y en último término, y esto es o más importante, por estimar que después de mis declaraciones hechas en el mitin del

\footnotetext{
${ }^{9} \mathrm{AH}, 20-2$, p. 87.
} 
domingo es de grandísima violencia el tener que sostener una conversación de esta naturaleza con el Sr. Presidente de la República» ${ }^{10}$.

Como era de prever, Prieto no está nada conforme con las palabras de su compañero presidente. Y cree que por ningún concepto puede el partido «inhibirse de responder a las preguntas que le formule el Presidente de la República sobre la manera que debe resolverse la crisis». Aun estimando «muy dignas de tener en cuenta» las manifestaciones de Largo, cree que se debe nombrar un compañero de la comisión ejecutiva para que acuda a $\mathrm{Pa}$ lacio. Fernando de los Ríos hace suyas las palabras de Prieto y añade que, si ellos no acudieran a la consulta, después de la declaración hecha en el Parlamento, la gente que vive ajena a los acuerdos del PSOE tendría la impresión de que «éste se colocaba fuera del régimen republicano declarando que no

${ }^{10}$ Aquí Largo se refiere sin duda a su reciente discurso en el mitin de los tranviarios, celebrado en el cine Europa, de Madrid, el día 1 de octubre. Abundando en la última parte en lo ya dicho sobre la conquista del poder político, hace a lo largo de su intervención un repaso autocrítico de la labor de los socialistas en la República, ponderando la lealtad, pero lamentando haber sido demasiado complacientes en varias de sus conductas: dejar marchar a la familia real, mantener las leyes e instituciones monárquicas, votar al primer presidente... Tras elogiar a Manuel Azaña y a sus Gobiernos, confiesa que en los últimos tiempos deseaban salir del poder, pero con dignidad, sin ser arrojados del mismo: «Al Partido Socialista se le ha expulsado del Poder de una manera indecorosa. El Partido Socialista y la clase trabajadora consciente de España no podrán olvidar más que, después de hace lo que hicieron, se les haya despedido de la forma que se ha llevado a efecto». Además, han sido sustituidos por «algunos hombres que eran sospechosos para el Comité revolucionario». Y en clara alusión al presidente de la República: «Y por la misma persona que fulminó la recusación sobre cierto hombre, por sospechoso [Guerra del Río], se le ha refrendado el nombramiento para que pertenezca al Gobierno que hoy nos rige». Y, poco más adelante: «Se ha dado el Poder a los saboteadores de la República, a aquéllos que hacía tiempo venían teniendo a la República y al Parlamento en jaque con una obstrucción incomprensible. En premio a aquella labor, se les ha llamado a ocupar el Poder». Tras una larga carga de profundidad contra Lerroux, su partido y el Gobierno que, teniendo la confianza de Alcalá Zamora, ha venido gobernando las últimas semanas sin tener la confianza aún del Parlamento - toda una situación anticonstitucional-, recuerda el repúblico socialista el acuerdo tomado por el partido de quedar absolutamente libres «para obrar con arreglo a las circunstancias políticas, una vez que los republicanos han cancelado - ellos no nosotros- todos los compromisos que tenían contraídos. Y añade: De colaboración en el Gobierno, a mí me parece que esto ya está terminado (Aplausos). De lo demás el Partido lo examinará». Tiene «la convicción íntima» de que el Partido Socialista no votará la confianza, que al día siguiente va a pedir Lerroux en la Cámara. («Muy bien. Grandes aplausos», leemos tras esas palabras en la transcripción del discurso). Pero teme que los republicanos que se llaman de izquierda la voten, aunque sólo sea por miedo a la disolución de las Cortes. Esta vez no acertó. Dentro de unos días los socialistas iban a verse en similar aprieto. Azaña, M., Obras completas: Memorias politicas y de guerra, Ediciones Oasis, México, 1968, t. V, pp. 183-185; El Socialista, 3 de octubre de 1933.Según algunas fuentes, tras los párrafos en los que se criticaba, sin decir el nombre, al presidente de la República, se oyeron gritos entre el público de « ¡Abajo el Botas!». 
le interesa ni poco ni mucho la suerte del mismo». Y propone que acuda el vicepresidente de la ejecutiva y diputado por Valladolid, Remigio Cabello.

Habiéndose ratificado Caballero en sus declaraciones anteriores, por estar «moralmente obligado» a ellas, sin querer por eso dejar incontestada la consulta, la comisión ejecutiva entrega a Cabello las conclusiones acordadas para que responda a las preguntas que le formule el jefe del Estado:

«Primero: Para la solución que debe darse a la crisis han de constituir punto de partida los efectos constitucionales de la votación recaída ayer en el Parlamento, efectos que para evitar cualquier equívoco deben tenerse en cuenta incluso en la forma en que se decrete el cese del Gobierno, al que tan explícitamente han negado su confianza las Cortes.

Segundo: Debe procurarse la formación de un Gobierno capaz de actuar con las Cortes Constituyentes que siguen siendo un instrumento útil, Gobierno que, si mantiene íntegramente el espíritu de las Leyes de la República sin intentar retrocesos políticos, no encontraría por parte del Grupo Parlamentario Socialista hostilidades nacidas de ningún prejuicio.

Tercero: Ese Gobierno debiera estar constituido con tal ponderación y amplitud de representaciones, que, en caso de que adviniese el momento de disolver las Cortes - momento que no es el actual, a juicio del Partido Socialista-, constituyese una garantía para todos los partidos».

Terminada la consulta en palacio, el vicepresidente del partido manifiesta a sus compañeros de dirección que en su entrevista se ha atenido en un todo al criterio acordado anteriormente, y añade que, «al preguntarle el presidente de la República si el Partido Socialista ofrecería su colaboración en un Gobierno nacional que se formase para realizar las elecciones, ha contestado que su opinión particular es la de que por el Partido socialista no habría inconveniente en formar parte del nuevo Gobierno que se formara con esa finalidad». Y con estas palabras se cierra la reflexión sobre la situación política: «Es aprobada por la Ejecutiva la gestión».

Al día siguiente, con la comisión al completo y con los dos representantes del grupo parlamentario ya mencionados, continúa la reflexión sobre la situación política ${ }^{11}$. Largo informa haber recibido la visita de Felipe Sánchez Román, encargado de formar Gobierno, que quería conocer el criterio del PSOE «para la concesión de representante nuestro en dicho Ministerio, cuya función principal había de ser la disolución del Parlamento».

Prieto, que ve a primera vista que se trata de un solo posible ministro socialista, se muestra esta vez contrario a la aceptación, por «las enormes dificultades» que para un solo compañero «-un compañero nuestro- representaría actuar en el Gobierno con la responsabilidad de toda la acción ministerial frente a los requerimientos que se le hicieran por las organizaciones obreras y socialistas». Vidarte «hace suyas» las manifestaciones de Prieto, «en el sentido de aceptación del cargo» (sic). Y más retóricamente Pascual

${ }^{11}$ AH, 20-2, p. 88. 
Tomás, contrario a esa aceptación, se refiere a «los camaradas que se nombren ministros» y a su dificultad de controlar la acción de Gobierno, dadas las «dificultades del momento político», cuando tanto Caballero como Prieto han hablado de un solo representante socialista.

Fernando de los Ríos discurre de muy diferente manera: «Estima de intensa gravedad la situación política de España y considera imprescindible la colaboración socialista en el Gobierno, a fin de que se pueda desde allí controlar las elecciones y garantizar a la vez la pureza en la acción del Gobierno que se formara». Del Toro, Carrillo, Fabra, Cabello, De Gracia y Negrín «se muestran conformes con criterio sustentado por el compañero De los Ríos y por lo tanto contrarios de tener participación ministerial en Gobierno presidido por el Sr. Sánchez Román» (sic). Tal es la escritura literal.

Caballero, que hace el resumen de lo dicho por todos, sustenta la misma opinión que De los Ríos, «por estimar que con la participación socialista se realiza una función altamente beneficiosa para los intereses de los trabajadores y, además, porque se podrá vigilar en todo detalle la función que realice el Gobierno en (sic) carácter electoral».

Puesta a votación la propuesta, votan en contra Prieto y Tomás, «y todos los demás en sentido favorable». Pero hacen constar la salvedad de que «por ningún motivo se colaboraría en un Gobierno en el cual figuraran ministros derrotados en el Parlamento, pertenecientes al Gobierno Lerroux».

El acta del 5 de octubre no pasará de cierto a la historia de la literatura. Y el sindicalista Pascual Tomás, secretario de actas, habrá escrito el acta más incorrecta de su vida. Pero la salvedad final se cumplió al pie de la letra. Los socialistas interpretaron el artículo 75 de la Constitución en el sentido de que ningún ministro del anterior Gobierno derrotado en el Congreso podía presidir un nuevo Gobierno, ni siquiera pertenecer a él, interpretación que no compartía el presidente de la República, ni el de las Cortes, ni los letrados de la Cámara, ni don Alfonso González Posada. ${ }^{12}$.

Según Juan Simeón Vidarte, Gregorio Marañón invitó también al partido socialista a participar en el gabinete, más que todo «para una fiscalización electoral», pero se topó con el muro antisocialista del partido radical, que, como veremos en seguida, no era el criterio del ex ministro Diego Martínez Barrio. De todos modos el grupo parlamentario socialista aprobó esa participación por 35 votos contra $8^{13}$.

El último intento, «in extremis» y con nocturnidad, lo llevaron a cabo Azaña, Domingo y M. Barrio, que, por iniciativa del primero, visitaron, la

${ }_{12}$ Artículo 75 de la Constitución republicana: El Presidente de la República nombrará y separará libremente el Presidente de Gobierno, y, a propuesta de este, a los Ministros. Habrá de separarlos necesariamente en el caso de que las Cortes les negaren de modo explícito su confianza.

13 Vidarte, J. S., Las Cortes Constituyentes de 1931-1933, Grijalbo, Barcelona, 1976, p. 660 . 
noche cerrada, a don Alejandro Lerroux en su casa para que levantase el veto al PSOE, cosa que lograron.

El autor de los Diarios nos ha contado la escena, casi novelesca ${ }^{14}$. A la vuelta de la casa de «don Ale», que los recibió en la alcoba, volvieron al Congreso cerca ya de la madrugada del día 8. Allí se tropezó Azaña en un pasillo con Largo Caballero, quien le dijo que, de haberlo sabido a tiempo, le «habría aconsejado que no hiciera la visita». Los tres visitantes del domicilio del jefe radical fueron al despacho del presidente de las Cortes y allí se les juntaron Indalecio Prieto y Fernando de los Ríos, a quienes comunicaron el éxito de la visita. Tras consultar al grupo parlamentario socialista,»don Inda» se puso a pergeñar una difícil nota explicando cómo, a pesar de lo dicho sobre el artículo 75, el partido socialista seguía en el Gobierno. Mientras el socialista se afanaba en lo suyo, Azaña intentó convencer a Martínez Barrio, el segundón radical, de que presentara su Gobierno a las Cortes y retrasara la disolución de las mismas así como las elecciones. Pero no le convenció. No quería el político sevillano presentar al Gobierno en la Cámara por miedo a que el presidente de la República fuese zarandeado por algunos que interpretaban torcidamente el artículo 75 , y porque partidos de la mayoría gubernamental se habían allanado ya a la necesidad de disolver; incluso los socialistas: "Los socialistas pretenden cohonestar su entrada en el Gobierno y sus declaraciones sobre el artículo 75, precisamente porque este nuevo Gobierno está llamado a presidir las elecciones y quieren vigilarnos, digámoslo así».

En ésas estaban cuando vieron y oyeron que Prieto, enojadísimo, renunció a escribir la nota. No le salían más que «paparruchadas»; colérico, rasgó los papeles y los arrojó a la papelera. La próxima disolución de las Cortes - comenta don Manuel- aconsejaba la presencia de los socialistas, «pero la cólera entre radicales y socialistas había llegado a tales extremos, que la propia honradez de los sentimientos de Prieto se atravesaba como un obstáculo insuperable». Se levantó éste y allí concluyó todo. Eran las cinco de la mañana. M. Barrio quería salir de allí y llevar la solución al presidente a primera hora de la mañana. «¿Y qué se hace?», preguntaba Domingo. «¿Qué se va a hacer? -dijo Besteiro-, formen ustedes Gobierno los republicanos». Los otros asintieron.

«El caso es -termina diciendo Azaña, que aprovecha el viaje para sacar a moraleja política- que los socialistas desistieron. Los diputados del grupo parlamentario se habían ido a dormir. No había lugar a más deliberaciones. Y cada cual se fue a su casa. Los socialistas que han estado más de tres años

${ }^{14}$ Azaña, M., Obras completas, IV, op. cit., pp. 647-648. Coincide con el relato fundamental de Azaña, en lo que a la visita domiciliaria atañe, Alejandro Lerroux, añadiendo algunos picotazos irónicos sobre sus tres visitantes, y una nota cultural pintoresca: estaba el acostado leyendo "por enésima vez El Quijote». Lerroux, A., La pequeña historia: Apuntes para la historia grande vividos y redactados por el autor, op. cit., pp. 180-182. 
propalando que fueron expulsados del Gobierno, y atacando a los republicanos de izquierda que dieron ministros al Gobierno para disolver las Cortes, no dicen verdad ni tienen derecho a censurar a nadie. Ellos iban a entrar en el Gobierno «como en una mesa electoral», no solamente sabiendo el programa de disolver las Cortes, sino porque iban a ser disueltas».

Juan Simeón Vidarte, testigo de algunas escenas de esa noche y confidente del presidente de las Cortes, Julián Besteiro, testigo de algunas otras, añade algunos detalles relevantes de la intrahistoria socialista, que confirman el susodicho juicio de Azaña ${ }^{15}$.

Tras la vuelta de los comisionados de casa de Lerroux -visita que éste confirma en sus memorias- se reunieron los tres ex-ministros socialistas en el despacho del presidente de las Cortes y encontraron «la fórmula salvadora»: todos los partidos que habían rehusado la confianza al jefe radical suscribirían una proposición declarando que los efectos de aquel voto no alcanzaban a su ministro Martínez Barrio, sino sólo al candidato derrotado.

En letra cursiva transcribe Vidarte la resolución de la comisión ejecutiva: «Reunida la Comisión ejecutiva, decidimos, pasadas las tres de la mañana, colaborar con el Gobierno a efectos de fiscalización electoral». La misma comisión autorizaba a los ex-ministros para designar a la persona que había de ir al nuevo gabinete en representación del partido.

A las cuatro de la madrugada, el grupo parlamentario socialista, tras oír a Caballero y Prieto, aprobó una larga nota, redactada por el ex ministro de Obras Públicas -no satisfactoria, según confesión propia-, que parecía justificar la no entrada en el nuevo Gobierno, y tanto debió de ser así, ique el presidente del grupo, el «caballerista» Remigio Cabello ¡tuvo que recordarles a sus compañeros que acababan de votar la participación socialista, con un representante, en el nuevo gabinete de Martínez Barrio!

Éste último les dijo a los tres ex-ministros en el despacho de Besteiro que había pensado en Vidarte, como futuro ministro socialista, ya que no había sido «duramente combatido por las oposiciones», como todos ellos. Al presidente de las Cortes, además, le completó la confidencia, como proveniente del mismísimo don Alejandro, que le había pedido que no fuera el nuevo titular socialista «ninguno de los que tanto le habían combatido».

Volvieron de la reunión del grupo parlamentario socialista los ex-ministros, que dieron el visto bueno a la designación de Vidarte. Prieto entonces comenzó a redactar una nueva nota, que diera cuenta leal del cambio de posición, y es cuando se desesperó al no encontrar la manera de manifestar la contradicción, al tener que decir, según esta nueva versión, «que lo blanco es negro», y al partido "cada hora una cosa distinta». Esta versión intrapartidista acaba con Prieto dándose por vencido, y prometiendo a Martínez Barrio la aceptación de su Gobierno y la cooperación de los votos socia-

15 Vidarte, J. S., Las Cortes Constituyentes de 1931-1933, op. cit., pp. 658-673. 
listas, siempre que respondiera a «las directrices de lo que fue el Comité revolucionario» ${ }^{16}$.

Prieto y Largo sí lograron, en cambio, al día siguiente, redactar una nota escueta y explicar sin mayor dramatismo que no podían participar en un gabinete presidido por quien constitucionalmente no podía hacerlo.

Por fin, don Niceto pudo encomendar con todas las formalidades al tenido como lugarteniente del «Jefe»-«el segundo brillante de Lerroux», como él mismo se llamaba, no sé si con la complacencia de aquél- formar un gabinete de «concentración republicana», con el objetivo de disolver la Cámara y presidir las elecciones legislativas ${ }^{17}$.

El día 8 de octubre quedó constituido el Gobierno, presidido por Diego Martínez Barrio, Gran Maestre del Gran Oriente Español, a cuya excelencia masónica han atribuido algunos autores el éxito de tan delicada operación política $^{18}$. Los ministros eran: 2 radicales; 3 radical-socialistas, uno por cada

${ }^{16}$ Martínez Barrio cuenta esta última parte de manera lacónica, y sólo habla de su visita a Besteiro, que le trasmite el acuerdo final de los suyos: «La dirección del partido agradecía mi oferta, pero no la aceptaba. Preferían quedar al margen del Gobierno». Martínez Barrio, D., Memorias, Planeta, Barcelona, 1983, p. 203.

17 «Al negarle los ex ministros socialistas - no la Comisión ejecutiva ni la minoríauna participación directa en el Gobierno, decidió [el presidente de la República] disolver el Parlamento», escribe Vidarte, que recibe la noticia del presidente Besteiro y nos lo trasmite «como un recuerdo de ultratumba». VidarTE, J. S., Las Cortes Constituyentes de 1931-1933, op. cit., p. 676.

18 Para la relación entre masonería española y política en este período, GómEz MoLLEDA, M. D., La masonería en la crisis española del siglo XX, Taurus, Madrid, 1988, pp. 395 y ss. Diego Martínez Barrio, cabeza de la corriente más izquierdista de su partido, reelegido triunfalmente Gran Maestre en la asamblea nacional ordinaria, celebrada en Barcelona, junio de 1933, encabezaba al mismo tiempo el ala moderada, más masónica y apolítica, de la Obediencia más importante de España: no por nada su nombre simbólico era «Vergniaud». En el discurso posterior a su reelección, lamentó el grave daño causado a la Masonería por los afiliados que habían llevado a las logias «las luchas de la República y de sus partidos políticos, cosa atribuible a algunos Hermanos mal acomodados con la enseñanzas de la Orden». Su juicio no pudo ser más severo: «La inversión de la conciencia espiritual de algunos masones es notoria. Son hombres de partido primero; masones, después. A esta regla moral acomodan sus su conducta e inyectan en el ambiente sereno de los talleres el morbo de las pasiones profanas, como si fuera posible y útil dotar a la Institución un perfil doctrinal que la identificara con cualquier tendencia política e incluso con cualquier régimen político». Ibidem, p.483. Frente a esta actitud estaba el grupo más político y extremista, uno de cuyos dirigentes era el secretario del Gran Consejo, desde octubre de 1932, Ceferino González Castroverde, simpatizante socialista al menos, si no afiliado, con el que comulgaban, antes o después de instaurada la República, otros masones socialistas como Daniel Anguiano, ex secretario general del partido; Graco Marsá (republicano radical desde 1931); y los diputados constituyentes Romualdo Rodríguez de Vera («Venerable» de la logia «Mare Nostrum»), Luis Martínez Gil, Antonio Fabra Rivas, Enrique de Francisco, Mariano Moreno, Juan Simeón Vidarte, 
una de las dos facciones más uno no alineado en las mismas; 2 independientes; 1 de ERC; 1 de AR; 1 del PRG; 1 de IRS, y 1 del partido progresista (PP), fundado por Alcalá Zamora a finales de $1931^{19}$. Los masones, según el masón Vidarte, esta vez eran seis, incluido el presidente del Consejo ${ }^{20}$.

No le perdonó nunca don Alejandro a don Niceto esta preterición, este olvido de su personalidad por la de un hombre, al que está lejos de llamarle su segundo en sus comentarios posteriores: «un hombre en formación todavía, un hombre sin historia y sin mundo, sin autoridad personal ni fuerza propia». Al presidente le atribuye la «maniobra» de querer quebrantarle a

Luis Jiménez de Asúa, José Ruiz del Toro, Rodolfo Llopis, Tomás Álvarez Angulo... Las logias «Mare Nostrum» (1927) y «Primero de Mayo» (1931) de Madrid, estaban compuestas mayoritariamente por socialistas. Según el fiable testimonio de Vidarte, del centenar y medio, aproximadamente, de diputados masones en las Cortes, «sólo 30» eran socialistas, Vidarte, J. S., Las Cortes Constituyentes de 1931-1933, op. cit., p. 136.

19 Pensaba Lerroux -nos desvela Martínez Barrio, y así lo hace ver sin rubor el mismo don Alejandro, como veremos- que el presidente de la República volvería a encargarle el nuevo Gobierno, y tenía preparada ya una lista de ministrables: algunos radicales de su círculo íntimo, que le habían acompañado en su frustrado gabinete y otros republicanos de varia procedencia: M. Barrio, Botella, Barnés (Domingo), Rocha, Guerra del Río, Lara, Gordón, Rico (Pedro), Iranzo, Samper, Companys, Niembro, Cirilo del Río, Barcia y De Buen, casi todos ellos masones. Su lugarteniente respetó algunos de estos nombres, y otros, como el del radical histórico Rocha, no. Ni el radical-socialista Palomo, ni el independiente Rico Avello, ni el izquierdista catalanista Pi y Sunyer, nuevos ministros, estaban en aquella lista. Martínez Barrio, D., Memorias, op. cit., p. 201.

20 Vidarte, J. S., Las Cortes Constituyentes de 1931-1933, op. cit., p. 678. En los primeros gabinetes republicanos el número fue similar o mayor. Eran masones el Gran Maestre, Martínez Barrio; Fernando de los Ríos y Marcelino Domingo, ambos vocales del Gran Consejo Federal Simbólico (1931-1933), que nunca asistieron a las asambleas masónicas después de su nombramiento; Álvaro de Albornoz, Santiago Casares Quiroga, José Giral, Manuel Azaña (desde el 2 de febrero de 1932), que nunca más pisó una logia. Todos ellos pertenecían al Grande Oriente Español (GOE). El masón más antiguo de los ministros era Alejandro Lerroux, el único bajo la Obediencia de la Gran Logia Española, la antigua Federación Catalano-Balear del GOE, quien, durante muchos años «durmiente», pidió la «plancha de quite» en su primitiva logia de Barcelona, y se afilió en la logia «La Unión» de Madrid, bajo la jurisdicción del Grande Oriente Español, después del sonado ingreso de Azaña en esta misma Obediencia, y como contraposición al mismo. La logia había sido fundada por jóvenes republicanos radicales a finales de la Dictadura. En noviembre de 1932 fue disuelta por el Gran Consejo, basándose en ciertas irregularidades, pero el motivo mayor parece hacer sido el carácter «lerrouxista» de la misma, cuando era máxima la oposición del líder radical al Gobierno de Azaña. «La Unión» se adscribió entonces a la Gran Logia Española. A pesar de esto, en sus memorias escribe: «Uno, que apenas pasó de los dinteles del templo, «duerme» hace 50 años «el sueño de los justos», mirando con benévolo desdén esas organizaciones arcaicas». LERROUX, A., La pequeña historia: Apuntes para la historia grande vividos y redactados por el autor, op. cit., p. 186. 
él y dividir al partido radical, para daño de la República y la Patria, porque de las elecciones que el nuevo presidente del Consejo convocó provinieron las dificultades con que luego tropezaron todos los Gobiernos posteriores ${ }^{21}$.

La IV Asamblea Nacional de Acción Republicana, celebrada los días 14 a 16 de octubre, fue más agitada que las anteriores, en las que había dominado imperturbable la figura señera de Manuel Azaña, el fundador y presidente. Aunque, tras varias propuestas más extremosas de la izquierda del partido, el tema de las alianzas electorales quedó apartado de la ponencia política, sí fue recogida la aspiración de formar en España un solo partido republicano de izquierda, con un llamamiento especial a los partidos regionales y autonomistas para que se integraran en el mismo. Azaña fue elegido con el máximo número de votos (271), y como vicepresidente, su fiel amigo Mariano Ruiz Funes (270), miembro de la comisión constitucional, reconocido criminalista y catedrático de la universidad de Murcia, por donde fue elegido diputado. Entre los vocales vemos al exministro y catedrático de química José Giral y a Claudio Sánchez Albornoz, diputado por Ávila, catedrático de historia, rector de la universidad de Madrid e historiador, prestigioso, representante de AR en los dos últimos Gobiernos de Lerroux y Martínez Barrio. No por nada al partido Acción Republicana se le llamó el «partido de los catedráticos».

\section{ANTE LAS ELECCIONES A CORTES.}

El día 12 de octubre, firmó el presidente de la República, junto al decreto de convocatoria de elecciones legislativas, el decreto de disolución de las Cortes Constituyentes, redactado por él mismo, en el que explanaba los motivos de la misma; entre ellos, los cambios habidos en el cuadro de los partidos políticos, así como los cambios en «los estados de opinión», de los que eran expresión pública las dos elecciones celebradas ese mismo año. El consejo de Ministros lo aprobó por unanimidad, con alguna salvedad sin importancia ${ }^{22}$.

José María Gil Robles nos ha contado ${ }^{23}$ que ese mismo día, convocadas ya las elecciones, vieron muchos la necesidad de constituir una especie de

${ }^{21}$ Lerroux, A., La pequeña historia: Apuntes para la historia grande vividos y redactados por el autor, op. cit., pp. 187-189. Al comienzo de este amargo comentario dispara Lerroux su dardo contra Alcalá Zamora: «Don Niceto no ha procedido en ningún momento -triste es decirlo- con alteza de miras ni con grandeza de alma». Y le reprocha, no sólo en este momento, «inclinaciones, simpatías y debilidades» para con los socialistas.

22 «En rigor de verdad - escribe el entonces presidente del Consejo, que acompañaba con su firma el decreto del presidente de la República-, a las Constituyentes no las mataba el ejercicio de la facultad presidencial, sino su propia obcecación». MARTínez BARRIO, D., Memorias, op. cit., p. 204.

${ }^{23}$ Gil Robles, J. M., No fue posible la paz, Ariel, Barcelona, 1968, pp. 95-96. 
comisión ejecutiva, en que estuvieran representados los partidos CEDA, Renovación Española, los tradicionalistas y los agrarios de la antigua minoría. Pero la comisión -de la que él mismo era miembro-, compuesta por ocho parlamentarios del grupo parlamentario agrario, fue sólo un «comité de enlace», sin facultades normativas, que tuvo «un papel de amigable composición en aquellos pleitos en los que no fuera posible zanjar por medio de negociaciones directas las aspiraciones contrapuestas de los grupos políticos». Dicho comité redactó el día 14 tres bases, «que forjaron aquella unión y que sirvieron de instrumento eficacísimo para la propaganda electoral». Rezaba la primera: «Revisión de la legislación laica y socializante desenvuelta tanto en el texto constitucional como en las demás leyes». La segunda: «Una rigurosa defensa en el futuro Parlamento de los intereses económicos del país, reconociendo a la agricultura su legítima preponderancia como base de la riqueza nacional». La tercera: «Amplia amnistía, tan pronto se constituyan las Cortes, para todos los delitos políticos con la misma generosidad con que fue concedida a los responsables del movimiento revolucionario de agosto de 1917 ».

En el Monumental cinema, de Madrid, el día 15 de octubre ${ }^{24}$, inicia José María Gil Robles la campaña electoral, con un mitin, en el que, al contemplar «el suelo de la Patria, cubierto de escombros, tras dos años de persecución sañuda, injusta, tiránica, cruel contra la derecha», comparable sólo a las de Rusia y Méjico, sueña con una nueva reconquista, iniciada como la anterior desde tierras de Castilla. Frente a la «revolución arrolladora», en trance de ser vencida, y la derecha, convertida en la encarnación de nuestra «tradición gloriosa», la lucha contra el marxismo del partido socialista es objetivo primordial, y para ello llama a formar el frente más amplio: «Para mí, la necesidad del momento presente es una derrota implacable del socialismo». Pero más allá de la victoria electoral señala como tarea fundamental de su generación «el hacer una España nueva, el hacer un Estado nuevo, el hacer una Nación nueva, una Patria depurada de masones, de judaizantes, de separatistas...».

Lo que propone el joven catedrático salmantino es «una España próspera y fuerte, en el seno de la cual queden implacablemente ahogados todos los gérmenes de división y anarquía por una justicia social impuesta con férrea

${ }^{24}$ Gil Robles, J. M., Discursos parlamentarios, Ed. Taurus, Madrid, 1971, pp. 269270 y Elorza, A., La utopía anarquista bajo la Segunda República. Precedido de otros trabajos, Ayuso, Madrid, 1973, pp. 264-266 (hay una versión algo distinta del mismo discurso en el diario El Debate y en el boletín quincenal del partido, C.E.D.A, órgano de la Confederación Española de Derechas Autónomas).- El profesor e historiador Carlos Seco Serrano, autor del estudio preliminar al grueso libro que recoge esos discursos, editado y preparado por el profesor Pablo Beltrán de Heredia, no puede menos de escribir cuando elogia los fines positivos de la campaña gilroblista de 1933: «Pero el ardor oratorio le lleva a afirmaciones demasiado arriesgadas, tan arriesgadas, que las izquierdas no las olvidarán jamás», GIL RoBles, J. M., Discursos parlamentarios, op. cit., p. XXIX. 
mano a los de arriba y a los de abajo». Una «unidad espiritual de España a todo riesgo: porque, si vamos a labrar un mundo nuevo no es mucho pedir que se desangre esta sociedad, si es que de ella ha de salir la salvación de la generación futura» $»^{25]}$. Una «verdadera unidad, un sentido nuevo que nos enlace con lo que se llama política totalitaria del momento presente». Y ante ese ideal no se van detener «en formas arcaicas»: «El Parlamento, el parlamentarismo, cuando llegue el momento, jo se somete o desaparece!».

Por parte socialista, en la sesión del día $11^{26}$, el presidente de la comisión ejecutiva comunica a sus colegas haber recibido en su casa la visita del ministro de la Gobernación, cuyo nombre no se $\mathrm{da}^{27}$, «el cual le ha ofrecido en términos de gran consideración ser dentro del Gobierno como respecta a los intereses de todos los partidos, sin producir la menor violencia en contra de nadie» (sic). Y se decide «trasladarle las demandas que se han presentado sobre suspensión de Ayuntamientos y otras anormalidades por el estilo».

Ante la proximidad de las elecciones, la dirección socialista acuerda dirigir a todas las agrupaciones una circular que recoge los acuerdos del último congreso del partido «con relación a la forma de elegir los candidatos», recordándoles a la vez la obligación que tienen «de no pactar alianzas con ningún partido político, sin antes realizar la correspondiente consulta a la Comisión Ejecutiva».

Según la ponencia sobre designación de candidatos, que se aprobó en el XIII congreso, las agrupaciones de cada provincia debían decidir en un congreso provincial los nombres de los compañeros que habían de ser elegidos para representarla y, de acuerdo con las organizaciones de UGT, realizar la campaña electoral. La comisión ejecutiva podía proponer nombres de candidatos que incluir o excluir de las listas aprobadas por agrupaciones o federaciones, «si hubiera razones que lo aconsejaran», pero éstas tenían la última palabra, con la obligación de dar cuenta de los acuerdos en el primer congreso nacional que se celebrase.

La comisión electoral estaba formada, desde el 12 de abril de 1933, por De Francisco y Vidarte (de la CE), Andrés Saborit (de la UGT), José Ruiz

${ }^{25}$ Tal vez a esta frase se referirá Fernando de los Ríos, cuando el día 22 de ese mes, en un mitin en Granada, pedirá serenidad frente a las declaraciones de Gil Robles. RuIZ Manjón, O., Fernando de los Ríos: Un intelectual en el PSOE, Síntesis, Madrid, 2007, p. 377.

${ }^{26} \mathrm{AH}, 20-2$, p. 89. Sobre todo lo referente al partido socialista y las elecciones legislativas de 1933, abundantes noticias, opiniones y datos en la obra MARTín NÁJERA, A., El grupo parlamentario socialista en la Segunda República: estructuras y funcionamiento, 2 vol., Ed. Pablo Iglesias, Madrid, 2000, pp. 363-402.

27 El reconocido abogado asturiano Manuel Rico Avello, ex secretario de la organización patronal minera de Asturias, diputado por esa circunscripción, ahora independiente tras haber pertenecido al grupo parlamentario Al servicio de la República, partido y grupo ya disueltos. 
del Toro (del Grupo Parlamentario), y Emilio Antonio Cabrera (por Juventudes Socialistas); en octubre se añadieron, por la UGT, Trifón Gómez, y los suplentes Félix Galán, administrador de El Socialista, y el sindicalista Enrique de Santiago, redactor del mismo periódico. En esta sesión, la comisión electoral comunica que se reunirá todos los días para determinar la labor de la campaña electoral, teniendo ya acordado la redacción de «un manifiesto de carácter general, en el cual se recojan todas las aspiraciones del Partido y de la clase trabajadora», y propone que el compañero Prieto se encargue de la redacción del mismo; lo que es aprobado por unanimidad. Se acuerda asimismo celebrar en Madrid un acto público, en el que intervengan los compañeros Caballero, Prieto y Fernando de los Ríos.

«Extra chorum» parece cantar Vidarte cuando propone literalmente «que la ejecutiva autorice a las Federaciones provinciales para pactar alianzas por sí mismas con elementos republicanos que formaron parte con nosotros del primer Gobierno de la República». ¿A qué Gobierno se refería el ex diputado por Badajoz y secretario primero de las Cortes: al Gobierno provisional del 14 de abril de 1931, presidido por Niceto Alcalá Zamora, o al formado por Manuel Azaña el 15 de octubre del mismo año? Intervienen Cordero y otros miembros de la CE y se acuerda «sostener el criterio adoptado por el Comité nacional».

En la siguiente sesión del día $12^{28}$, en la que «disculpan su asistencia» (sic) Cabello y Fabra, la comisión ejecutiva conoce la carta enviada por el PRRSI, de Marcelino Domingo, en la que el comité ejecutivo nacional del mismo le pide la decisión de los órganos autorizados del PSOE «acerca del propósito de coalición nacional o provincial con los demás partidos de izquierda, que como el nuestro antepone a todo su propósito de defensa de la República y de los ideales que juntos nos llevaron a las Cortes Constituyentes para que éstas fueran el cauce de la obra revolucionaria». Les gustaría tener una entrevista antes de tomar resolución de carácter definitivo sobre coaliciones y alianzas. La CE, acuerda contestarle por mediación de Caballero y De Francisco, «que nos atenemos en un todo a los acuerdos adoptados por el Comité nacional sobre el particular».

La comisión electoral da cuenta del criterio sustentado en su reunión por los representantes de la Unión General de Trabajadores «sobre la conveniencia o no de alianzas electorales con los partidos republicanos, ateniéndose a los acuerdos adoptados por el Partido sobe este particular». En ella Trifón Gómez solicitó levantar un empréstito de 300.000 pesetas para sufragar los gastos de la campaña electoral. El dinero podría ser solicitado de la Cooperativa socialista, de la UGT y de la Institución Pablo Iglesias, garantizándose la devolución de lo prestado con el diez o el veinte por ciento que abonarían de sus dietas los diputados que fuesen elegidos. Puesto a debate el asunto, la

${ }^{28}$ Ibid., p. 90. 
ejecutiva acepta la negociación de dicho empréstito y la forma de devolverlo, con los votos en contra de Caballero, Carrillo y Cordero.

En la sesión del 18 de octubre ${ }^{29}$, a la que faltan Fabra, Carrillo y De Gracia, la comisión electoral concreta ya en 100 pesetas la cantidad que deberán pagar los diputados mensuales que no tengan más sueldo que las dietas, y los que tengan otro sueldo que las dietas pagarán aquella cantidad para el fondo electoral y el tanto por ciento que les corresponda para el sostenimiento del diario El Socialista.

En esa sesión y en las de los días 27 y 31 del mismo mes $^{30}$, entre la muy variada mezcla de noticias referentes a las elecciones que envían muy distintas agrupaciones, he aquí lo que me parece más atinente para nuestra información general:

-Buena parte de las sugerencias o peticiones de las distintas agrupaciones o federaciones son enviadas por la comisión ejecutiva a la comisión electoral. Otras veces, cuando se trata de cuestiones individuales, a las agrupaciones o federación interesadas o responsables.

-En ocasiones, y a petición de algunas agrupaciones (Málaga, Toledo) la comisión ejecutiva designa directamente al candidato.

-Se acepta la propuesta de la federación socialista de Valencia para ir en conjunción electoral con Acción Republicana y los radical-socialistas.

-Se acepta la propuesta de alianza entre el PSOE y la Federación Provincial Obrera (que no pertenece a UGT) de Salamanca, «porque es la única forma en que puede conseguir triunfar en la próxima contienda electoral».

-Se acepta asimismo, la actuación de la federación de Pamplona (por Navarra), donde «todas y cada una de las Agrupaciones que la integran» rechazaron la alianza electoral con los republicanos, pero poco después la CE se da por enterada de los intentos de esa misma federación por negociar con los republicanos de izquierda la candidatura de minorías y, en caso negativo, por estudiar una candidatura de mayorías con los radical-socialistas independientes. Con razón se le faculta al secretario de la CE (De Francisco), en caso de una nueva consulta, para que les informe sobre los acuerdos ya tomados por el comité nacional y la comisión ejecutiva ${ }^{31}$.

-En cuanto a las alianzas con los comunistas, que desean las federaciones de La Coruña y de Sevilla, se les responde que «pueden hacerlo siempre que sean requeridos previamente por los comunistas, no autorizando jamás el que el Partido haga la petición de alianzas para la lucha electoral». Era, por lo demás, el criterio mantenido para toda clase de alianzas.

\footnotetext{
${ }^{29}$ Ibid., pp. 91-95.
}

${ }^{30}$ Ibid., pp. 96-101.

${ }^{31}$ Los socialistas navarros fueron por fin solos y no lograron -tampoco sus interlocutores republicanos- un solo diputado. En las elecciones legislativas de junio de 1931, la conjunción republicano-socialista había conseguido los dos diputados de la minoría: uno de AR y otro del PRRS. 
-A veces, la CE envía a uno de sus miembros (v.g., Antonio Fabra a Ciudad Real), en caso de conflictos enojosos, incluida la exclusión de candidatos. Y se aprueban ciertas elecciones, que en principio no eran fáciles, de cuyo desarrollo dan cuenta los miembros presentes de la dirección, como en el caso de Cáceres, a donde fue enviado el secretario-tesorero Enrique de Francisco.

-Cuando algunas agrupaciones advierten del peligro de que sean elegidos ciertos candidatos de dudosa o mala conducta, la ejecutiva aconseje hacer una nueva reunión y «designar en ella a los hombres que puedan dar una mayor preponderancia a las ideas y a la organización en dicha población». Pero la agrupación tiene siempre la última palabra, a veces en contra de la propuesta de la CE.

-Ésta no interviene en otros casos conflictivos personales «por el solo hecho que lo haya planteado una organización de la provincia»: Espinardo, en Murcia, o Jerez de los Caballeros en Badajoz.

-Se resuelven algunas dudas de compañeros que preguntan por la compatibilidad de algunos de sus cargos.

-Algunas agrupaciones protestan por haberse celebrado el congreso provincial antes de las votaciones («antevotaciones») en las mismas: Oviedo y Sama de Langreo. Se pide información a la federación de Asturias.

-La CE se da por enterada de las renuncias de algunos candidatos a la candidatura en ciertas circunscripciones; por ejemplo, Lucio Martínez Gil, ex diputado por Jaén, renunció a esa circunscripción para quedarse con las de Badajoz y Madrid capital; fue elegido por esta última.

\section{CANDIDATURAS ELECTORALES. EL FIN DE LA CONJUNCIÓN REPU- BLICANO-SOCIALISTA.}

Entre los gubernamentales republicanos de izquierda ${ }^{32}$ Acción Republicana formó 7 candidaturas en solitario; participó en 16 candidaturas de republicanos de izquierda, incluidos los federales; en 12 con el PSOE (Vizcayacapital y provincia, Valencia-capital y provincia, Baleares, Cádiz, Castellón, Guadalajara, Huesca, Logroño, Santa Cruz de Tenerife y Teruel), y en 7 con republicanos de centro (radicales) y de derecha. El PPRS presentó 13 candidaturas exclusivas; participó en 9 republicanas de izquierda; en 6 republicano-socialistas: Burgos Logroño, Málaga-capital (PRRS+PSOE+PCE), Santa Cruz de Tenerife, Segovia y Teruel, y en 7 con republicanos radicales. Por su parte, el PRRSI formalizó 10 candidaturas en con sus propios militantes; participó en otras 10 republicanas de izquierda; en 12 republicanosocialistas (Vizcaya-capital, Valencia-capital y provincia, Murcia-capital y provincia, Sevilla-provincia (con federales), Burgos, Cádiz, Castellón,

${ }^{32}$ Avilés Farré, J, La izquierda burguesa en la II República, Madrid, 1985, pp. 211224; Martín NÁJera, A., El grupo parlamentario socialista en la Segunda República: estructuras y funcionamiento, op. cit., pp. 366-384. Y elaboración propia. 
Cuenca, Huesca, Teruel...) y en una con los radicales. ERC hizo coalición con el PSOE en Tarragona y con Unió Socialista de Catalunya en las dos circunscripciones de Barcelona, Gerona y Lérida, y también con los federales en Barcelona-provincia y Gerona. En Valencia En Las Palmas de Gran Canaria el PSOE fue en alianza con los federales. El PRG se alió con los radicales en La Coruña, con AR en Pontevedra y se presentó solo en Lugo.

Como se ve, hay toda clase de divisiones entre los republicanos. Pero el PSOE tampoco se presentó tan solo como Largo daba a entender en discursos y declaraciones ${ }^{33}$, o como el mismo Manuel Azaña afirmaba, cuatro años más tarde, en su ya mencionado Cuaderno de la Pobleta ${ }^{34}$. Fue coaligado

${ }^{33}$ En una entrevista para El Liberal, de Madrid, publicada el 19 de octubre, declara Francisco Largo Caballero que el partido socialista «está hondamente dolorido de las desconsideraciones que ha sido objeto por parte de los núcleos republicanos, no de sus hombres más representativos, sino de las masas que les siguen». Y llega a decir: «Se nos ha perseguido a sangre y fuego en todo el ámbito nacional, intentando, no diré por quién, deshacer nuestras organizaciones, claro está que sin conseguirlo». Lo que pesa mucho a la hora de las alianzas. Pone como modelo el caso de la agrupación socialista de Madrid, que va sola a las elecciones, y sola hubiera ido, aunque hubiera sabido que así no iban a sacar un diputado. Cree que igual táctica se seguirá en provincias, «con alguna excepción sin importancia: por ejemplo, Valencia, en que vamos unidos con Acción Republicana y con los radicales socialistas independientes». LARGo CABALlero, F., Obras completas, volumen V. Escritos y discursos (1933-1934). Edición a cargo de Aurelio Martín Nájera y Agustín Garrigós Fernández. Fundación Largo Caballero (Madrid)-Instituto Monsa de Ediciones (Barcelona), 2003, p. 1857. En sus discursos electorales, sin concretar como aquí, emplea a menudo el mismo argumento. Alguna mayor concreción hace en su discurso pronunciado en Zafra (Badajoz), el día 30 de octubre, donde, tras elogiar su participación en la instauración y consolidación de la República lamenta todo lo sucedido después: «Pero se nos echó y desde momento están cancelados todos los compromisos con los llamados afines. Ahora se lamentan de que el Partido Socialista no vaya aliado con los republicanos a las elecciones. ¿Qué culpa tenemos nosotros? Es verdad que estuvimos en el Gobierno con los republicanos y que aquellos hombres se esforzaban en ser leales. Pero en provincias como ésta sus correligionarios hacían todo lo contrario. ¡Eso no lo puede olvidar la clase obrera!». Ibidem, p. 1888.

${ }^{34}$ Manuel Azaña considera que «la ruptura de la coalición electoral en noviembre de 33, es el mayor dislate político cometido después de disolver las Constituyentes en tan mala oportunidad». Recuerda que los socialistas se negaron a una coalición general pactada, «a pesar de que muchos de ellos la aconsejaban, como Prieto». Acababan de retocar la ley electoral, dejando subsistente el sistema mayoritario, con una fortísima prima a la mayoría, que mantuvieron todos los partidos del Gobierno, «y principalmente los socialistas por boca de Largo», porque con él los partidos de izquierda, en coalición, estaban seguros de conseguir «una mayoría compuesta». Y añade su amarga decepción: «Pues, bien: a las pocas semanas de votada la ley, hecha sobre el supuesto de subsistir la coalición, los socialistas la rompían, para luchar solos, con lo que, además de renunciar a las ventajas del sistema, las ponía enteramente, como una masa, en manos de la coalición de derechas y radicales, que en sus misma narices estaba formándose. Es inconcebible, pero así ocurrió. No hubo razonamientos capaces de convencerles. Hice cuanto pude. 
con diversos partidos republicanos de izquierda en 24 de entre 59 circunscripciones (un 40\%) y en una de ellas también (Málaga-capital) con el PCE y el PRRS, que salieron vencedores en la segunda vuelta. En la agrupación socialista de Madrid, en la elección previa de candidatos, Largo Caballero, con 681 votos, superó a Besteiro, que consiguió 631.

Los discursos electorales del presidente del partido, recogidos casi siempre al pie de la letra por el diario oficial El Socialista, y trasladados después a sus Obras completas por la Fundación que lleva su nombre, son, junto con algunas declaraciones a ciertos periódicos, una fuente imprescindible para conocer bien la historia real del partido, del socialismo español y de buena parte de la España por esas fechas. De estilo directo, austero y claramente pedagógico, sin una concesión a cualquier adorno literario, pero con suficientes recursos oratorios para ilustrar, convencer y conmover a sus oyentes, el exministro Caballero, vitoreado constantemente como «el Lenin español», llenaba por estas fechas plazas y teatros de poblaciones de primer o segundo orden, del sur y centro de España, y entusiasmaba a muchos miles de personas.

Él no se consideraba un orador, y así lo reconocía públicamente. Pero su reiterado mensaje, pleno de sobria claridad, basado en un marxismo elemental de forzoso optimismo histórico, que anunciaba la necesaria revolución social por medio de la inevitable dictadura del proletariado, y reforzado por su autoridad de severo e infatigable ministro de Trabajo y Previsión Social, valía en aquel momento de crisis económica y social, y en medio de una delicada situación política de la joven República, mucho más que la mejor retórica tradicional de los grandes oradores políticos españoles.

El candidato socialista por Madrid-capital venía ante todo a decir lo que había que decir a los trabajadores, a la clase obrera española. Hasta entonces no había podido decirlo, porque estaba en los Gobiernos de la República, y, además, en el ministerio de Trabajo, desde donde veía las dificultades que oponían al cumplimiento de la legislación social patronos y autoridades; de salir a la plaza, hubiera tenido que ser para denunciarlo: «Los camaradas De los Ríos y Prieto - declaraba en el teatro Popular de Murcia, el 14 de noviembre de 1933- podían hablar de la política escolar, de las obras hidráulicas. Pero yo no hubiera podido hablar más que de la situación social, y esto hubiera sido enfrentar a la clase obrera con la Republica ${ }^{35}$.

Basta esta breve cita para intuir que Largo tenía «necesidad» de ajustar las cuentas con el régimen al que había servido desde la alta institución del ministerio. Lo vimos ya antes incluso de dejar sus responsabilidades. Y lo

Inútilmente». Más adelante deja patente su desconocimiento de la realidad electoral en 1933, o, en este caso, su mala memoria: «Creo que la agrupación de Bilbao, por influencia de Prieto, fue la única que mantuvo la alianza electoral». AzAÑA, M., Obras completas, IV, op. cit., p. 649.

35 Largo Caballero, F., Obras completas, volumen V. op. cit., p. 1930. 
fue expresando a lo largo de su gira electoral. Suele llamar «los errores de la República». Y el primero se le antoja, como ya vimos, «el movimiento pacífico» del 12 de abril de 1931,»que entonces nos pareció digno de alabanza». Pero, según el tribuno socialista, «el pueblo español ha visto que en vez de agradecerle su gesto pacífico, quieren volver a sojuzgarle de nuevo». Y añade, amenazante: «No les extrañe que si la historia se repite y es preciso volver de nuevo a un movimiento revolucionario, éste no sea pacífico. Y la culpa será de ellos».

El segundo error, que ya señaló en su conferencia de Ginebra, fue aceptar precipitadamente desde el Gobierno provisional la convocatoria inmediata de unas Cortes, «antes de hacer la revolución, para que luego la hubiera sancionado el Parlamento». Que a nadie le extrañe que, en parecidas circunstancias, el pueblo se acuerde de tal error ${ }^{36}$.

Unos días más tarde, en Salamanca, al hablar de sus dos años en el Gobierno, declara a la pata la llana: «Entonces fuimos unos ingenuos. Mantuvimos todas las instituciones -el tercer error citado en otras ocasiones-. Cometimos la torpeza de proclamar pacíficamente una República (Ovación). Ahí tenéis las consecuencias: March se ha fugado; el señor La Cierva vuelve a España. Y hasta la familia de Martínez Anido se halla en Madrid. La reacción está completamente envalentonada. (...) Ahora, si la clase trabajadora volviera a realizar un movimiento, ¿podría olvidar esa experiencia? Lo natural es que no la olvide» ${ }^{37}$.

Ni que decir tiene que, si a todo eso llama errores, por errores mucho mayores tiene los dos últimos Gobiernos republicanos y todo lo que han traído consigo, como veremos. Todo lo cual le enfrenta con sus antiguos compañeros, los llamados republicanos de izquierda, y, no digamos, con los republicanos radicales, sus colegas en los dos primeros Gobiernos provisionales.

Es otro de los estribillos de sus discursos: los partidos republicanos, incluidos los llamados de izquierda, no representan nada ni a nadie. Culpables fueron por aceptar en un primer momento el Gobierno de Lerroux y culpables por aceptar el de su sucesor Martínez Barrio, que siempre consideraron los socialistas como anticonstitucional. Pero «la principal responsabilidad» de todo lo que acaezca en el país «será de quien realizó tamaña arbitrariedad (Gran ovación)»; el mismo que, «por defender la República, echó al último Gobierno Azaña, en el que participaban los socialistas, a pesar de contar con la confianza del Parlamento». Clara alusión al presidente de la República en el primer Gobierno Lerroux ${ }^{38}$.

36 Discurso en Don Benito (Badajoz), 8 de noviembre, Largo Caballero, F., Obras completas, volumen V. op. cit., pp. 1899-1900.

37 Discurso en el teatro Bretón, de Salamanca, día 15 de noviembre, Ibidem., pp. 1951-1952.

${ }^{38}$ Discurso en Albacete, 12 de noviembre, Ibid., p. 1919. Cuenta Gabriel Mario de Coca que al final del mitin, un grupo de mujeres le regaló al orador una pluma esti- 
Y, si «el Lenin español» muestra siempre una cierta devoción para con sus colegas y amigos Azaña, Casares y Domingo, llega a afirmar, en cambio, de Acción Republicana y del Partido Radical-Socialista, «que como partidos no han cumplido bien. No puede esperar nada de ellos la clase trabajadora». Ya no tienen misión histórica alguna que cumplir. ¿El laicismo? ¿Las libertades políticas? Eso ya lo defienden los socialistas. Los partidos republicanos intermedios «coinciden con las derechas a la hora de defender la propiedad privada: son enemigos como ellas de la socialización. En cuanto se llega a lo fundamental, a la supresión de los explotadores, ¡ah!, entonces ya no quieren nada con nosotros». Cuando, apenas formado el Gobierno de Martínez Barrio, un periodista, pregunta a Largo sobre un posible «partido de izquierda», que estaría formándose, responde aquél contundentemente que «los socialistas no formarán jamás en esa comunión" ${ }^{39}$.

Pero la mayor virulencia ideológica y oratoria del exministro se reserva para el partido radical de Lerroux. Ahora -dice en el mitin de Zafra-, aquel partido que censuraba a los socialistas por aprobar el voto de la mujer, porque «el voto femenino entregaría la República a la reacción», se alía con el «frente antimarxista»: el partido Reconstrucción nacional (sic) de Goicoechea, «de carácter monárquico y fascista»; el «partido fascista (...) presidido por Calvo Sotelo, del cual es presidente (sic) Martínez Anido» (Una voz: ¡valiente asesino!) ${ }^{40}$; Acción Popular de Gil Robles; las derechas agrarias. ¡Con todos los que no votaron la Constitución y conspiran contra la República! Al mentar a dos partidos republicanos conservadores, coaligados también con algunos de los anteriores, se ríe del diminuto partido progresista (PP), creado por Alcalá Zamora, «que está compuesto de tres filas de a uno», y arremete contra el ex ministro, Miguel Maura, presidente del PRC, su colega en el primer Gobierno provisional, a quien acusa nada menos que de haber ordenado cañonear la Casa de Cornelio en Barcelona y de dar órdenes a la guardia civil para que disparara sin previo aviso, según telegrama encontrado por su sucesor Casares Quiroga en el ministerio de la Gobernación ${ }^{41}$.

Los radicales -clama en otra ocasión- «son los que están facilitando la vuelta de la monarquía. No hay más que ver quién defendió a March en las

lográfica para que firmara los primeros decretos de la Revolución proletaria, según la dedicatoria suscrita por ellas. Coca Medina, G. M., Anti-Caballero: Crítica marxista de la bolchevicación del Partido Socialista (1930-1936), Engels, Madrid, 1936, p. 122.

39 Entrevista con Pedro Masa, El Liberal, 19 de octubre, Largo CABAllero, F., Obras completas, volumen V. op. cit., p. 1859.

${ }^{40}$ Sin duda quiere decir «vicepresidente», como le llama en el discurso en Azuaga Badajoz), el 9 de noviembre. Largo Caballero, F., Obras completas, volumen V. op. cit., p. 1916. El partido de Calvo Sotelo, que era el mismo del de Goicoechea, se llamaba propiamente Renovación Española.

${ }^{41}$ Discurso en Zafra (Badajoz), 30 de octubre, Ibidem, pp. 1881-1882. 
Cortes. No hay más que ver quién es el ministro radical que ha dicho que no se podía pedir la extradición de un hombre que ha cometido un delito común $\rangle^{42}$. Lerroux, el presidente del PRR, es ahora el mismo que un día defendió la guerra de Marruecos, y el que un día, si llega al poder, puede embarcar a España en otra guerra «que se está incubando en Europa» ${ }^{\text {»3113 }}$. Al viejo caudillo radical, que acusa al PSOE de ser «un partido en el que se refugian todos los licenciados de presidio», Largo le echa al rostro un proceso por estafa incoado ya en el año 1895 , y, más cerca, el no haber sido llamado a declarar tras el golpe del 10 de agosto sobre su relación y encuentros con el general Sanjurjo y otros implicados en la asonada. Sin olvidar a su fiel edecán Rafael Guerra del Río, hoy ministro en el Gobierno republicano de Martínez Barrio, a quien el mismo que hoy le presta confianza -alusión al presidente de la República- le recusó, siendo presidente del Comité Revolucionario en 1930, por sospechar que estaba en relaciones con el gabinete monárquico de entonces ${ }^{44}$. Viejas historias: nuevas ofensas.

\section{HACIA LA REVOLUCIÓN SOCIAL VIOLENTA.}

Pero, al fin y al cabo, estos malhadados republicanos burgueses, de izquierda o de derecha, aliados ahora con los mayores enemigos de la República, no son sino parte necesaria de la «democracia burguesa = dictadura burguesa», que los socialistas han venido a destruir y a cambiarla por la «dictadura del proletariado». ¿Qué entiende FLC por aquélla? «La democracia burguesa no es más que una composición de palabras. Os lo dice un hombre que ha sido ministro dos años y medio. La democracia burguesa es una mentira». En la República (léase: en la República española) el obrero no puede votar libremente, si no quiere estar condenado al hambre. «¿Es eso democracia? $\gg^{45}$

Cuatro días antes, lo explica mejor ante 12.000 obreros, explanando en Jaén ${ }^{46}$, el triple lema de la Revolución francesa, en versión marxista, «el se-

${ }^{42}$ Discurso en Don Benito, cit., p. 1901.

43 Discurso en el teatro popular de Murcia, 14 de noviembre, Ibid., p. 1904.

${ }_{44}$ Discurso en el Monumental cinema de Madrid, 17 de noviembre, Ibid., pp. 19581962. En su libro de memorias, Caballero llama a Lerroux «el inmoral por excelencia». Largo Caballero, F., Mis recuerdos: cartas a un amigo. Con prólogo y notas de Enrique de Francisco, Ediciones Unidas, Méjico, 1954, p. 128.

45 Discurso en Azuaga, cit., p. 1911.

46 Discurso en la plaza de toros de Jaén, 5 de noviembre, p. 1890. Largo no sólo había sido ministro, sino, unos años antes, consejero de Estado durante la Dictadura primoriverista, si bien elegido en representación de los vocales obreros del Consejo de Trabajo, antes Instituto de Reformas Sociales, del que era vocal desde el año 1904. La decisión fue autorizada por las comisiones ejecutivas del PSOE y de la UGT, y después aprobada por los respectivos congresos. La versión del autor, en LARGO CABALLERO, F., Mis recuerdos: cartas a un amigo, op. cit., pp. 89-94. Ese mismo día, 5 de noviembre, se aprobó 
ñuelo con que se engaña a la clase obrera para que coopere a ese género de revoluciones». Fraternidad: «mientras haya explotados y explotadores hay lucha de clases, y mientras haya lucha de clases, no hay fraternidad posible». Libertad: ni siquiera es posible la libertad religiosa en este régimen. «Existe la esclavitud económica, y mientras exista eso, la libertad es una ficción. Igualdad: mientras haya seres que tengan en sus manos todos los medios de producción y de cambio, y otros que sólo tengan su fuerza de trabajo, la igualdad no podrá existir».

La democracia burguesa es una verdadera dictadura: «El solo hecho aplica el orador su pensamiento general a la situación española- de que de que haya una mayoría burguesa en el Parlamento es una dictadura». Porque en esa situación «la burguesía hace las leyes a su medida; crea tribunales de justicia, que no hacen justicia, cuya única misión es defender la propiedad individual, o sea garantir los intereses de la clase capitalista»; crea un ejército permanente, compuesto de proletarios, no para garantizar la integridad de la patria, «sino para defender los intereses capitalistas, no los de la clase obrera, lanzando a los proletarios unos contra otros, y crea, además, una fuerza publica para ir contra los trabajadores, como se ha venido haciendo en la República». Como se ve, la crítica a la República, que él mismo y su partido han colaborado decisivamente a levantar y sostener, no puede recibir una crítica más severa ${ }^{47}$.

De la dictadura burguesa al fascismo, tan de moda ya en aquellos años, no hay mucha distancia. Cuando el candidato socialista por Madrid-capital habla en Jaén de la «amalgama antimarxista», que lucha en la campaña electoral contra los socialistas, dice que el peligro para la clase obrera es más inminente de lo que parece: En España, «a ciencia y paciencia de los Poderes públicos, se está desarrollando el fascismo. Ya se atreven a celebrar actos públicos; ya se manifiestan sin disfraces. Y la autoridad, no sólo los tolera, sino que los protege». Si el día 19 los fascistas son derrotados, «es fácil que intenten hacer algo extralegal». Y la amenaza es inequívoca: nadie podrá tachar a los socialistas si van contra ellos, «sin respetar ni cosas ni personas. (...) Si se salen de la ley, nos saldremos nosotros también. Y ya veremos quién pierde más» ${ }^{48}$.

en referéndum el proyecto de Estatuto Vasco por el $84 \%$ de los electores vascos $(459.255$ votos contra 14.196, pero en Álava llegaran los votos positivos sólo al 46\%. Hubo una fuerte abstención de socialistas, republicanos y tradicionalistas.

${ }^{47}$ Discurso en el teatro popular de Murcia, cit., pp. 1934-1935. Luis Araquistain resume bien, en marzo de 1934, el pensamiento de su amigo y jefe político: «Nuestras ilusiones republicanas del 14 de abril se han desvanecido. Y el dilema no es ya Monarquía o República, República o Monarquía. No hay más que un dilema, ayer como hoy, hoy como mañana: dictadura capitalista o dictadura socialista. LARGo CABALLERo, F., «Discursos a los trabajadores (1934)», Obras completas, volumen V. op. cit., 1934. Prólogo, p. 2009.

${ }^{48}$ Discurso en la plaza de toros de Jaén, cit., p 18. Socialistas del ala centrista, como 
Días más tarde, al glosar en Murcia el quinto lema electoral del Frente Antimarxista, «Marxismo: exaltación de la fuerza. Antimarxismo: Respeto al derecho», entra de lleno en el panorama político español: «Pero es que se da el caso de que son los propios enemigos los que pretenden imponerse por la fuerza. Están organizando el fascismo. Y el Gobierno lo sabe, y permite que tengan locales, que publiquen periódicos, y conoce los nombres de los directores; pero, sin embargo, todavía no han encarcelado a ninguno. (Grandes aplausos. Se dan mueras al fascismo) ${ }^{49}$.

Ya era de prever que, hablando en Salamanca, no aludiera el orador a la candidatura agraria, encabezada por José María Gil Robles, el ex diputado agrario por esa provincia, que en marzo pasado había fundado la CEDA (Confederación Española de Derechas Autónomas) -partido que aparecía para muchos como favorito en la próxima contienda electoral-y era miembro, como hemos visto, del comité de enlace de los partidos que habían formado el Frente Antimarxista. A Gil Robles le echa en cara su reciente viaje a Berlín, pasando por Biarritz y París, invitado por la embajada alemana, en su calidad de periodista, «para asistir al desfile que los nazis habían organizado en Alemania». Allí el político católico español, según Largo, «se ha enterado de la organización de los nazis, que pretende trasladar a nuestro país $»^{50}$.

Prieto, según veremos luego, se acercaban en algunas entonaciones a la oratoria «caballerista». El mismo Fernando de los Ríos, dirigente humanista y moderado, se soltaba en ocasiones el pelo también. Uno de sus biógrafos menos panegiristas cita estas palabras en uno de sus mítines electorales, que no se pueden entender, como tampoco las de la cita siguiente, sin conocer la tensa situación política española en aquellos días, y tampoco sin conocer la polémica abierta en la dirección y en las filas del partido socialista: «Queremos mantenernos dentro de la legalidad, pero si el enemigo se sale de ella para combatirnos, fuera de ella nos encontrarán también». Ruiz Manjón, O., Fernando de los Ríos: Un intelectual en el PSOE, op. cit., p. 378. Virgilio Zapatero, que propende a una biografía más ejemplarizante, cita unas palabras en un mitin del catedrático granadino, el 23 de octubre, cuando se encaraba con sus adversarios políticos y afirmaba que jamás se había pronunciado una palabra «para arrancar emociones de rencor». «Si llega-decía- ese acto de guerra social, digo como siempre: a vuestro lado, trabajadores, estaré. Pero óiganlo todos: Yo venía con el alma llena de dolor, con el corazón saturado de tristeza. ¿Es esto todo lo que la burguesía española ofrece como flor de humanidad, como posibilidades a la masa española? ¿Es esto? El no temer a la guerra social? Yo sí la temo hondamente, pero llegada la su hora, seré un soldado». Zapatero, V., Fernando de los Ríos: Biografía intelectual, Ediciones de la Diputación de Granada, Granada, 1999, p. 393.

49 Discurso en el teatro popular de Murcia, cit., p. 1939.

${ }^{50}$ Gil Robles nos dice en su libro de memorias que fue invitado, «como simple observador, al Congreso Nacionalsocialista de Nüremberg, sin dejarme arrastrar al campo totalitario, con cuyas excelencias pretendían deslumbrarme los organizadores de aquellos espectaculares desfiles de juventudes militarmente encuadradas». Concertada a la vez una entrevista con Hitler, el ministro de Propaganda Goebbels le comunicó por teléfono la noticia de la caída del Gobierno Azaña y le dijo que, en tales circunstancias, el Führer 
Pero el tribuno socialista no se contenta con el cabeza de la lista salmantina, sino que intenta desprestigiar también a otros dos integrantes de la misma: el propietario agrario local, tradicionalista, José María Lamamié de Clairac, y el notario y terrateniente Cándido Casanueva, ambos diputados por Salamanca en las Cortes Constituyentes, dentro de la minoría agraria. Al primero le acusa de haber viajado a París, donde ha visitado al general Emilio Barrera, ex capitán general de Cataluña durante la dictadura de Primo de Rivera, y exiliado tras el golpe de Sanjurjo, el 10 de agosto. Y ¿a qué fue el diputado salmantino a la capital francesa? «Pues seguramente a cumplir un mandato de la organización fascista a la que está afiliado». Y aquí, un detalle de muy mal gusto: «Porque el señor Lamamié, aunque os parezca mentira, dado su aspecto un tanto equívoco (Risas), es fascista. Quizá lo sea por eso mismo». Del notario Casanueva sólo sabe decir que fue acusado de estafador por un agente del Banco Hipotecario y llevado a los tribunales, asunto aún pendiente por un débito de 6.000 pesetas. Al final del apartado, dedicado a la candidatura enemiga, la tacha sin más de $\langle\text { fascista }\rangle^{51}$.

no tenía inconveniente en aplazar la entrevista unos meses; entrevista que nunca tuvo lugar. Gil Robles, J. M., No fue posible la paz, op. cit., p. 93. Pero, además de asistir, según sus propias palabras, «a las jornadas inolvidables» del Congreso nazi, dedicó dos días al estudio de la organización del partido en la «Casa Parda» de Hitler. Según un artículo suyo y unas declaraciones complementarias en La Gaceta Regional de Salamanca, en los días posteriores a su viaje, Gil Robles vio en el nazismo ciertos rasgos positivos, como la exaltación de los valores patrios, su carácter antimarxista y antiliberal, su aliento juvenil y optimista: «Frente al Parlamentarismo corrosivo, destructor de la unidad interna del poder, la autoridad fuerte concentrada en una sola mano. Frente a la disgregación ideológica de los partidos, una sola fuerza nacional nutrida de postulados simplicísimos Frente al liberalismo corrosivo, germen de todas las energías, un concepto totalitario del Estado, encauzador de las máximas energías de una raza». Gil Robles, J. M., La utopía anarquista, op. cit., pp. 263-264.

${ }^{51}$ Discurso en el teatro Bretón, de Salamanca, cit., pp. 1947-1948. Ninguno de los cuatro partidos que componían el Frente Antimarxista era, en rigor, fascista. Entonces y después podrían ser tildados de conservadores, tradicionales, corporativos, autoritarios..., pero no fascistas. Y menos que cualquier otro, a pesar de ciertos trazos propios del tiempo, Acción Popular o la CEDA, que integró a todas las secciones de Acción Popular y otras similares. En su discurso pronunciado en el salón Victoria, de Barcelona, el 21 de marzo de ese año, había definido J. M. Gil Robles el pensamiento de su nuevo partido ante el fascismo: «Afirmamos nuestra discrepancia radical con el fascismo en cuanto a su programa y en cuanto a la táctica que lo inspira. (...) Doctrinalmente, los movimientos fascistas son inadmisibles para quien afirma los postulados del Derecho público cristiano. Esas ideologías que de un modo genérico se conocen con el nombre de fascismo suponen la identificación de la nación y el Estado, la de éste con un solo partido político y anulan, en consecuencia, la personalidad individual. En cuanto no temple un profundo sentido cristiano los rigores lógicos del sistema, se cae, necesariamente, en un auténtico socialismo de Estado, que cada día se infiltra más en las naciones modernas». El presidente de la CEDA considera la concepción de fondo del fascismo una concepción «netamente 
Contra el fascismo (o lo que se tenga como tal), el líder revolucionario anima a sus oyentes de Jaén a rebasar a sus líderes, en caso de cualquier debilidad, de cualquier duda. No es que él dude de la UGT o del partido que preside: «Pero nadie está libre de flaqueza. Si eso llegara, sed vosotros mismos los directores de la acción revolucionaria».

Porque no basta defenderse contra el fascismo. Hay que pasar a la ofensiva. Al final de su peroración en la ciudad andaluza, el predicador de la doctrina marxista va mucho más lejos, pero pensando siempre en un tiempo mucho más cercano: «¡Hay que prepararse para ir a la ofensiva socialista! Mientras no se organice nuestra ofensiva, mientras nos limitemos a defendernos, estaremos a merced del capitalismo. (...) ¡A triunfar el día 19, que ese triunfo nos conducirá a otro que está muy próximo y por el cual se redimirá el proletariado! $\rangle^{52}$.

Es demasiado fácil votar el día 19 de noviembre. A otras acciones que exigen más energía y decisión se refiere el político socialista. Para lograr la igualdad de todos, para tener una clase trabajadora culta -lo que «no se logra con muchas escuelas»-, para resolver el paro obrero, que «es la gangrena que derribará al capitalismo. No se trata de ganar las elecciones para tener el gusto de arrebatar el triunfo a las derechas, sino para inaugurar una nueva etapa revolucionaria. Para que llegue a todos los ciudadanos la República, tiene que ser social y no burguesa: Tardaremos más o menos, pero no ocultamos que vamos hacia la revolución social ¿Cómo? (Una voz del público: Como en Rusia) No nos asusta eso. Vamos, repito, hacia la revolución social. Y yo digo que la burguesía no aceptará una expropiación legal. Habrá que expropiarla por la violencia. (Ovación)».

«Ya han iniciado -sigue diciendo Caballero- los enemigos la guerra y dicen por boca de Gil Robles que si el Parlamento no les sirve, irán contra él. Pues bien, nosotros respondemos: Vamos legalmente hacia la evolución de la sociedad. Pero, si no queréis, haremos la revolución violentamente (Gran ovación). ¿Que dicen los enemigos que esto es excitar a la guerra civil? Hay una guerra civil. ¿Qué es, si no, la lucha que se desarrolla todos los días entre patronos y obreros? Estamos en plena guerra civil. No nos ceguemos, camaradas. Lo que pasa es que esta guerra no ha tomado aún los caracteres que, por fortuna o por desgracia, tendrá inexorablemente que tomar». Y como si

panteísta, que viene a afirmar que todo es producto de una sustancia única, distinta sólo en lo accidental». Separan del fascismo al nuevo partido de inspiración cristiana, pero no netamente confesional, los procedimientos tácticos de aquél: «Es muy fácil encomendar la solución de los problemas políticos a la fuerza; pero resulta casi siempre imposible mantener la violencia en los términos previstos y evitar que se desborden las pasiones, sobre todo en pueblos individualistas como España, con una tendencia tan acentuada a los movimientos anárquicos». Gil RoBles, J. M., Discursos parlamentarios, op. cit., pp. 216-217.

52 Discurso en la plaza de toros de Jaén, cit., pp. 1893 y 1898. 
esa inexorabilidad fuera inmediata, al finalizar el mitin, dice que March se ha evadido de la prisión ${ }^{53}$; que acaso están a punto de volver varios generales a España; que la República está en manos de quienes, llegado el caso, no la defenderían, y que, si por cobardía hay quien entrega el poder al enemigo -alusión más que probable al jefe del Estado o al presidente del Gobierno, Martínez Barrio-, como el año 1923 lo entregó García Prieto a Primo de Rivera, «la clase obrera lo impedirá». ¿Cómo? «Como ya dije en Zafra. Por los medios que sean».

No está muy acertado quien fuera consejero de Estado al evocar aquel acontecimiento, que abrió pasó a la dictadura militar, lo que no impidió, por cierto, la clase obrera de entonces. Pero ahora todo es muy diferente, incluido el pensamiento del primer dirigente socialista, quien acaba animando a sus oyentes a salir a la calle en cuanto vean que alguien intenta un golpe de Estado: «Y ése será el principio de la República social, en la que se realice la igualdad económica. Tenemos que luchar como sea, hasta que en las torres y en los edificios oficiales ondee, no una bandera tricolor de una República burguesa, sino la bandera roja de la Revolución socialista" ${ }^{44}$.

\section{TODO EL PODER PARA LOS SOCIALISTAS ${ }^{55}$.}

Tales propósitos, que hemos ido viendo desarrollarse en el pensamiento del presidente del PSOE, desde el discurso del cine Pardiñas y durante toda la campaña electoral, volveremos a oírlos proclamados, con expresiones similares, en los siguientes discursos de Albacete, Salamanca y en el Monumental cinema de Madrid. En la ciudad manchega se plantea las varias alternativas del próximo Gobierno. Cree que será difícil que se les entregue el poder para «gobernar en socialista», en caso de un triunfo electoral, y, por otra parte, «queda descartada la colaboración», pues el partido socialista no va a vivir «de la benevolencia de sus enemigos». Y si los radicales no

${ }^{53}$ El último pirata del Mediterráneo» -como le llamó Cambó-, creador de la compañía Transmediterránea y de la banca que lleva su nombre, elegido, como vimos, miembro del tribunal de Garantías Constitucionales, había sido encarcelado en Madrid por el Gobierno republicano el 10 de junio de 1933, y trasladado más tarde a la cárcel de Alcalá de Henares, de donde se fugó, el 4 de noviembre, con la ayuda de varios oficiales de la prisión, para refugiarse en Gibraltar, uno de los centros más activos de sus negocios. La comisión de responsabilidades de las Cortes nunca sustanció su proceso. Juan March, que había sufragado, entra otras obras, la construcción de la Casa del Pueblo de la ciudad de Mallorca en 1928, acusó siempre a varios ministros republicanos de haberle pedido dinero para sufragar la revolución de 1930. Logró volver a ser diputado en las últimas Cortes de la República.

54 Discurso en Don Benito, cit., pp. 1904-1906.

55 El semanario de la Juventudes Socialistas, Renovación, en su número 113, del 14 de octubre de 1933, abría su primera página, a cinco columnas: «La consigna de nuestro partido para las elecciones [y con letra de pasquín, a gran tamaño]: ii Todo el poder para los socialistas!!». 
consiguen la mayoría de otros republicanos, ¿con quién se aliarán? ¿Con los monárquicos? «Si eso ocurre, la clase trabajadora española debería levantarse como un solo hombre para no tolerarlo (Gran ovación). Que se alíen para la lucha electoral no es honesto, no es decente. Pero un Gobierno de agrarios y radicales juntos en España, eso jamás (La ovación es formidable. El público grita: «¡Nunca!») Eso no puede ser. Pues, si eso no es fácil, ¿qué van a hacer? ¿Van a dar el Poder a Acción Popular? ¿Podríamos tolerar que se entregase a los enemigos declarados de la República? Si eso ocurriera, el pueblo debería imponer la sanción a los traidores ${ }^{56]}$.

No se entendería bien esta constante doctrina revolucionaria del repúblico socialista sin conocer la doctrina básica que sostiene sobre el Estado y la clase trabajadora. El Estado no está encima de ella, porque ella es el Estado. Ella es todo, como todo era para el abate Sièyes el tercer estado. Pero el doctrinario madrileño prefiere citar «El Estado soy yo, de aquel rey francés», para enlazar con el proletariado español de hoy: «En cuanto los proletarios tengan conciencia de clase, podrán decir con toda autoridad: «El Estado somos nosotros (Ovación) $»^{57}$. Por eso FLC, que cree que la disolución de las Cortes Constituyentes conduce inexorablemente - otra vez, lo «inexorable»- a la disolución del próximo Parlamento, a las puertas de otro período revolucionario, puede decir que las masas obreras no se van a lanzar esa vez a la calle para entregar el poder a la burguesía, por avanzada que sea. Nada de eso: «Si la clase obrera tiene que hacer de nuevo el esfuerzo y el sacrificio de ir a un movimiento revolucionario, que lo haga de una vez; pero que sea para traer una República suya, propia, socialista (Formidable ovación) $)^{58}$.

Los «enemigos» se asustan - comenta risueño en Murcia el candidato socialista masdrileño- oyendo hablar de la dictadura del proletariado, «recordando que está establecida en Rusia y que la preconizó Marx». Algunos de ellos creen que «es una especie de dictadura de Primo de Rivera (Risas)». No es así como la entienden los socialistas: «La dictadura proletaria no es el poder de un individuo, sino del partido político, expresión de la masa obrera, que quiere tener en sus manos todos los resortes del Estado, absolutamente todos, para poder realizar una obra de Gobierno socialista (Gran ovación) $)^{59}$.

El período transitorio, durante el cual la clase obrera, con todos los resortes del poder político en sus manos, realiza la obra de socialización y del desarme económico y social de la burguesía, es lo que los marxistas llaman dictadura del proletariado. Lo dice, como

tantas veces, un hombre que ha estado dos años y medio sentado en el banco azul. «Pero por estar en el banco azul no se gobierna». Hay que tener

${ }^{56}$ Discurso en Albacete, cit., pp. 1927-1928.

${ }^{57}$ Discurso en Azuaga, cit., p. 1912.

${ }^{58}$ Discurso en Albacete, cit., p. 1928.

59 Discurso en el teatro popular de Murcia, cit., p. 1934. 
«todos los gobernadores socialistas» ${ }^{60} . \mathrm{Y}$ «el poder judicial», hoy en manos de la burguesía. Y todos los resortes que instaure el propio poder socialista: Es preciso, para que haya este poder, «tener en la mano todas las palancas del Gobierno" ${ }^{\prime 1}$.

Para esa obra total «hay que terminar con las luchas entre la clase obrera». Y al afirmar esto, se dirige a los núcleos de trabajadores que, «por error», combaten a los socialistas. Pero, si van a los mismos fines y quieren acabar con la clase capitalista, que se une contra la clase obrera, "ipor qué nosotros -se pregunta lógicamente el ex secretario de la UGT- no hemos de borrar también odios y rencores para formar un apretado haz que combata eficazmente al enemigo común?». El público de Azuaga, puesto en pie -según el taquígrafo- tributa una entusiasta ovación al «Lenin español», que hace ademán de conseguir el silencio, lo que el entusiasmo del auditorio impide con sus vítores y aclamaciones.

Los socialistas también quieren que desaparezca el Estado, dice el líder marxista en clara alusión a los anarquistas, al que quieren «convertirlo en una entidad meramente administrativa, pero con la actitud equivocada que adoptan esos elementos lo que hacen es remachar los eslabones de la cadena que esclaviza al proletariado». Él que ha sido «el hombre más injuriado, más difamado» por los elementos obreros aludidos, da por olvidado todo lo que han dicho contra él, «en aras de la unidad obrera». Formidable ovación. «Vivas» a Largo Caballero y a la Revolución social, siempre de acuerdo con el taquígrafo. Y, en seguida, para complacer a los comunistas: «Cuando se habla por ellos de la implantación de un régimen como el que hay en Rusia, yo pregunto. Pero eso lo vamos a hacer unidos, ¿no? Unámonos, pues, y luego trataremos sobre cómo se debe hacer la revolución». Se repiten los aplausos $^{62}$.

${ }^{60}$ Con amarga ironía escribió el presidente Alcalá Zamora que los socialistas renunciaron desde el primer momento a tener gobernadores civiles, «sin duda para eludir las dificultades del orden público». Alcalá Zamora, N., Memorias, Planeta, Barcelona, 1998, p. 297.

${ }^{61}$ Discurso en Don Benito, cit., p. 1902.

${ }^{62}$ Discurso en Azuaga, cit., pp. 1913-1914. La seducción y hasta la fascinación que ejercía el régimen soviético no era sólo patente entre el ala «caballerista» del PSOE. Ya hemos visto antes el largo abanico de amigos y admiradores de lo que aquí popularmente se llamaba Rusia. Una buena parte de la juventud republicana de izquierda, como ya nos ha indicado antes Santiago Carrillo, participaba de parecido entusiasmo. "Antes que Alemania, preferimos para nuestro país un régimen análogo al de Rusia», se podía leer en la revista de los jóvenes de Acción Republicana, (JAR) del 18 de noviembre. Y frases como ésta: «Sabedlo, ciudadanos: si el dilema se plantea entre el fascismo y la revolución social, nosotros gritaremos con el mayor entusiasmo y con todas nuestras fuerzas: ¡Viva la revolución social!», AvILÉs FARRÉ, J, La izquierda burguesa en la II República, op. cit., p. 214. Marta Bizcarrondo, en su libro, considera entre las causas principales del giro bolchevizante lo que llama «espejismo soviético», ese entusiasmo que producía la intensa 
Es la ocasión en la que, sin citarlos («esos elementos»), tiene más en cuenta Largo Caballero al voluminoso y múltiple anarquismo español, especialmente de la Confederación Nacional del Trabajo (CNT). En todos sus discursos, que aquí he ido citando, excepto en el de Ginebra, no hay una sola alusión directa a los anarquistas, y menos a las repetidas insurrecciones, golpes de mano y huelgas políticas de los primeros contra los Gobiernos republicano-socialistas. En su peroración de Salamanca vuelve a hacer a los anarquistas y comunistas la misma petición que acaba de hacerles en tierras pacenses. «El hombre a quien más han odiado esos elementos», sólo les pide allí «un desarme, un olvido de los odios». Los socialistas no les van a exigir que disuelvan sus organizaciones para que vayan a las suyas: «Lo único que afirmamos es que la actitud abstencionista, así como las candidaturas comunistas entre las nuestras y las derechas, no hacen más que favorecer a la reacción $)^{63}$.

Por lo demás, en todas las intervenciones del presidente socialista que vengo analizando no hay traza alguna sobre el llamado «problema regio-

propaganda pro-soviética, llegada a todas partes, desde las películas de Einsenstein hasta las emisiones de Radio Moscú, donde los triunfantes planes quinquenales de Stalin se contraponían al decadente y agonizante capitalismo occidental, que había causado el caos bursátil y la crisis económica del año 1929. Los libros, folletos, artículos, que cantaban las excelencias del «paraíso socialista» se multiplicaban y estaban en manos de cualquiera. Miles de trabajadores españoles oían con avidez en las casas del pueblo, sociedades, cafés o bares, las noticias de la URSS durante las dos horas de radio soviética, los jueves y los sábados, que serían cuatro, dos años más tarde. En la misma UGT, a pesar de que su dirección está, por el momento, curada del contagio sovietizante, como le hemos oído a Besteiro, muchísimos afiliados a la organización participan de la misma fascinación popular y no sólo popular. La Federación Española de Trabajadores de la Banca, de la que es alma el miembro del comité nacional de la UGT, Amaro del Rosal, publica desde octubre de 1933 la Revista de Economía Socialista, hecha con artículos procedentes de la edición francesa Revista Económica de la URSS, la tierra de promisión del proletariado mundial. Bizcarrondo, M., Historia de la UGT: Entre la democracia y la revolución, III, Ed. Siglo XXI, Madrid, 2007, pp. 81-100.

${ }^{63}$ Discurso en el teatro Bretón, de Salamanca, cit., pp. 1950-1951.La primera «alianza obrera» en España se constituyó en Barcelona con un manifiesto que lleva fecha de 16 de diciembre de 1933, formada por: Bloc Obrer i Camperol, Unió Socialista de Catalunya, Federación Catalana del PSOE y UGT, organizaciones las dos primeras de neto carácter catalanista. A pesar de que Caballero no era partidario entusiasta de esa alianza, dio su aprobación para que entraran en ella las tres organizaciones socialistas de ámbito español. Es cierto que la UGT dio normas para el funcionamiento de tales alianzas, constriñéndolas a «una función meramente de relaciones cordiales entre los diversos elementos que las componían», pero pronto derivaron, según el mismo líder revolucionario, a constituirse en «cantones independientes, con autonomía, de ahí que se declarasen huelgas y movimientos esporádicos, todo ello sin consultar con nadie». LARGO CABALLERO, F., Escritos de la República: Notas históricas de la Guerra en España (1917-1940). Edición, estudio preliminar y notas de Santos Juliá, Ed. Pablo Iglesias, Madrid, 1985, p. 141. 
nal», que afectaba en aquellas calendas sobre todo a Cataluña y al País Vasco, pero también a otras regiones. Ni apenas sobre «el problema religioso» (que abarcaba entonces el cristianismo, la Iglesia y la actuación de los católicos), sobre el que en la literatura «largocaballerista» no hay más que algunas frases despectivas dispersas, casi todas propias de la tradicional Vulgata del anticlericalismo español, aunque en el discurso de Ginebra ya dijo lo fundamental sobre la cuestión.

Igualmente es de notar la falta de referencia alguna a incidentes graves habidos en la campaña electoral. Dentro del estribillo constante de la persecución y de la represión de los socialistas por la República burguesa, sólo encuentro en los discursos de FLC una protesta concreta contra los actos de violencia por la fuerza pública, que tuvieron lugar el 4 de noviembre, la víspera del discurso en Jaén, en la ciudad andaluza. Esa fuerza pública, «creada para perseguir a los enemigos de la República» (seguramente la Guardia de Asalto, creada por el nuevo régimen ), y que nunca se pensó que lo fuera «para apalear a los a los únicos republicanos que hay en España: los trabajadores socialistas. Aplausos $\rangle^{64}$. Conocemos también un telegrama enviado por Fernando de los Ríos al ministro de Gobernación, Manuel Rico Avello, protestando porque la guardia civil y elementos derechistas trataban de obstaculizar la propaganda socialista en la circunscripción de Granada; porque la Benemérita se había desplegado por el teatro de Baza, como si no hablase «un ex ministro del régimen», y porque un cabo del mismo cuerpo había impedido a la caravana electoral entrar en el pueblo de Zújar. Se quejaba a la vez de la «libertad de difamación» en periódicos y hojas de la provincia, permitidos y sellados por el Gobierno civil ${ }^{65}$.

Por su parte, el líder de la CEDA, José María Gil Robles, en sus discursos electorales y en sus memorias lamenta muy doloridamente «la relativa libertad en que se dejó a las izquierdas para cometer impunemente numerosos atropellos». Por ejemplo, la agresión al candidato de la Unión de derechas por la provincia de Madrid, Javier Martín Artajo (CEDA), el 25 de octubre, cuando regresaba de un mitin en Torrelaguna; el asalto, la noche del 4 de noviembre, del centro electoral de la coalición de derechas en Sevilla por unos pistoleros; y sobre todo el atentado en el teatro Cortes, de San Fernando, el día 12 del mismo mes, durante un mitin de Acción Ciudadana, llevado a cabo por pistoleros jerezanos, con una víctima mortal y una señora gravemente herida ${ }^{66}$.

En sólo dos mítines intervino Julián Besteiro durante la campaña electoral socialista, y uno de ellos fue en el cine madrileño Pardiñas, el 6 de de

\footnotetext{
${ }^{64}$ Discurso en la plaza de toros de Jaén, cit., p. 1889.

65 Ruiz Manjón, O., Fernando de los Ríos: Un intelectual en el PSOE, op. cit., p. 378.

${ }^{66}$ Gil Robles, J. M., No fue posible la paz, op. cit., p. 100.
} 
noviembre ${ }^{67}$. Su primera parte está llena de invectivas contra los partidos que, de hecho o de derecho, forman el Frente Antimarxista son, especialmente contra su antiguo partido, el PRR, o republicano radical de Alejandro Lerroux. El republicanismo histórico español, según el tribuno socialista, «carece en absoluto de sentido social», y si no lo adquiere, no sólo será «el peso muerto» de la República, sino que constituirá obstáculos y en algunos momentos «ocasionará trastornos que hubiera convenido evitar». Si el PPR no se modifica, «no puede ser un instrumento de gobierno en la República Española y hay que hacerle desaparecer». Son viejos políticos, indisciplinados, vanidosos y demagogos, sucesores de ciertos políticos románticos del XIX, que hasta «sienten ciertas debilidades y complacencia por los legítimos bandoleros de la España contemporánea». Alusión transparente a sus relaciones con el banquero Juan $\operatorname{March}^{68}$.

A Besteiro no se le escapa tampoco el nuevo fenómeno de la Falange, puesta de largo en el teatro de la Comedia de Madrid, el día 29 de octubre. El aludido Frente Antimarxista empieza para el orador en el partido radical y «acaba en ese brote, ridículo y empalagoso del fascismo español, que trata de aliar la erudición almibarada del señor Valdecasas con el arrojo revolucionario más impulsivo que documentado, que hace poco proclamaba desde la tribuna las excelencias de la dialéctica de los puños y de las pistolas $\rangle^{69}$.

${ }^{67}$ Largo Caballero, F., Obras completas, volumen III. op. cit., pp 101-115. El Socialista, del 7 de noviembre. Coca nos informa que Besteiro habló en la Casa del Pueblo de Madrid antes de la primera vuelta, donde llegó a decir que el presidente Roosevelt había logrado tipos más avanzados de reformas sociales que «los hechos por socialistas colaboradores de la burguesía», remachando siempre su tesis de la no colaboración con los partidos burgueses. Coca Medina, G. M., Anti-Caballero: Crítica marxista de la bolchevicación del Partido Socialista (1930-1936), op. cit., p. 115.

${ }^{68}$ Diego Martínez Barrio juzga muy severamente la catadura moral del diputado radical gallego Emiliano Iglesias - también masón, pero perteneciente a la otra obediencia hispana: la Gran Logia Española-, con quien se declara incompatible, así como de varios diputados radicales, la mayoría valencianos, a los que incluye en el «grupo de Emiliano Iglesias». Para él, el problema es Juan March. Y recuerda que el defensor jurídico del magnate es otro diputado radical, el abogado Tomás Peire. Martínez Barrio, D., Memorias, op. cit., p. 185. Peire fue elegido diputado por Ceuta en la segunda vuelta de las elecciones legislativas de 1933.

${ }^{69}$ El ya citado Alfonso García Valdecasas, junto con Julio Ruiz de Alda y José Antonio Primo de Rivera, -aludido también aquí por su famoso discurso- fue uno de los oradores del mitin de la Comedia, el día 29 de octubre de 1933. Doctor por Bolonia, catedrático de derecho en la universidad de Granada, diputado por su provincia en las Constituyentes, dentro de la conjunción republicano-socialista, fue secretario de la comisión constitucional en las Cortes, representando al grupo parlamentario Al servicio de la República, capitaneado por José Ortega y Gasset, partido y grupo que por estas fechas ya se habían disuelto. En 1932 dejó el partido de los intelectuales y fundó otro grupo semejante, llamado Frente Español, junto con José Antonio Maravall, Antonio Garrigues, 
Algo tienen en común «los nuevos y pimpantes fascistas», ese otro «brote de hombres geniales», con aquellos políticos del XIX: éstos también se sienten hombres superiores y quieren acabar con la democracia «para ser, dicen, la salvación del país», pero son, más que brotes geniales, «la vulgar aparición de unos cuantos hongos más o menos venenosos»».

Al grupo que acaudilla José María Gil Robles, también miembro de la comisión constitucional y portavoz habitual del grupo agrario en las Constituyentes, llama el candidato socialista «fascistas larvados», que tienen «horror a la democracia y al Parlamento, que es su expresión». Demagogos, que creen que la voz del pueblo es la voz de Dios, cuando «aquí no hay nada divino, todo es humano». Aunque la cita es incorrecta, Besteiro saca a la palestra la desdichada expresión del líder actual de la CEDA en su primer discurso electoral, y su viaje a la Alemania de Hitler, que ya le echó en cara Largo Caballero: «Gil Robles, bajo las influencias del espíritu hitleriano, recogidas en uno de esos viajes relámpago a Alemania, nos ha dicho: Procuremos someter al parlamento y, si no, lo desharemos. Y es de suponer que el nuevo Parlamento tenga el sentimiento de su propio decoro que han sabido mantener las Cortes Constituyentes»».

Tras dar cumplida cuenta de sus adversarios, el presidente de la UGT hace una intensa y extensa profesión de marxismo, que parece extenderla a todo el partido, ya que, según afirma, nunca han hecho distinción ente marxismo y socialismo, y ahora son más marxistas que nunca: «Somos marxistas y somos hombres que aceptamos genuinamente la lucha de clases»; esa lucha de clases que odian los partidarios de «la lucha de razas», que es «lo más bajo y lo más bárbaro». Y como marxistas, son «internacionalistas», sin dejar de amar por eso a su país, porque el nacionalismo agresivo, el fascismo, llama a la guerra. Y como marxistas, «pacifistas». Como marxistas, también «revolucionarios», y no sanguinarios. Los episodios sangrientos, dice con empeño Besteiro -queriendo alejar seguramente de sus oyentes la ecuación revolución $=$ revolución soviética- son más propios de las contrarrevoluciones, convencido de que las revoluciones «son cada vez más humanas, más elevadas, más generosas para el adversario, progreso que ha coincidido con la mayor participación del proletariado en las revoluciones».

La revolución marxista no consiste sino en «transformar a fondo el régimen económico actual, empezando por socializar los medios de producción y cambio», para que sean manejados a fondo por el capital. Pondera la grave crisis económica y social, con 30 millones de parados en el mundo, paro «hoy definitivo», que exige transformar el régimen capitalista y sustituirlo

María Zambrano, Antonio Sacristán... Candidato en 1933 en la lista radical-derechista de Granada, fue excluido de ella por su actuación fascista, a instancias de los radicales, aunque Fernando de los Ríos declaró que lo había sido más bien por haber atacado al capitalismo en su discurso de la Comedia: «El marxismo y el capitalismo me parecen despreciables». 
por un régimen de democracia económica. El deseo vivo de las masas es llegar hoy al socialismo revolucionario, compatible con el máximo posible de elementos liberales y democráticos, y esa debe ser la actitud general de todos los socialistas del mundo.

Entre las medidas más inmediatas y concretas, el ex presidente de las Cortes plantea la socialización de las principales industrias, de los bancos y de la tierra, «obra que hay que realizar lo antes posible para evitar los grandes males que están ocurriendo». En Alemania, el paro, la desesperación de los obreros y la desorientación de la clase media, caída en el proletariado, han acabado trayendo el nazismo ${ }^{70}$. Otra de las reformas pendientes consiste en completar la legislación social y el sistema de subsidios, que es claramente insuficiente. Y, en fin, todo «un plan ordenado de reconstrucción nacional», que abarca la educación, la higiene, los riegos, la producción y distribución de la energía motriz para el desarrollo industrial...

Imprescindibles le parecen al orador para todo esto el «mantenimiento de las instituciones democráticas, únicas que permiten a la opinión el control de la obra de los gobernantes, únicas que ofrecen garantías de la austeridad imprescindible del desempeño de las funciones públicas y de cuyo mantenimiento debemos los socialistas constituirnos en celosos guardianes». ¡Extraño lenguaje tras oír tantos discursos de Largo Caballero! Los socialistas, proclama a renglón seguido, son «la mayor garantía del mantenimiento de la moral en la vida pública».

Al final de su discurso, el que fue desde los nueve años alumno de la Institución Libre de Enseñanza, el discípulo de Giner, Salmerón, Caso o Simarro, hace una verdadera profesión de espiritualidad cívica y humanista: «Nuestros adversarios habrán de convencerse de que nuestra firmeza espiritual y moral es invencible. La nuestra, la «espiritualidad de los materialistas de la Historia», inspirados en las grandes ideas libertadoras de los intelectuales del siglo XVIII y en las ideas libertadoras de los socialistas del siglo XIX, aspiramos en nuestro siglo a libertar a la humanidad sometida a la esclavitud económica, para que las fuerzas del espíritu, hoy cohibidas, se expansionen y produzcan las grandes obras de la creación humana en una civilización fraternal, grande y fuerte».

${ }^{70}$ El mismo día en que salía a la luz pública la Falange, 29 de octubre de 1933, Luis Araquistain, que había vuelto de su embajada de Berlín, sustituido por Luis de Zulueta, tras dejar el ministerio de Estado en Madrid, daba una conferencia en la Casa del Pueblo de Madrid: «Una lección de historia: el derrumbamiento del socialismo alemán». Ni la Constitución liberal de Weimar, ni la gloriosa historia de la socialdemocracia alemana habían servido de nada ante la irrupción de las huestes hitlerianas. Sólo una firme «voluntad de poder» -era la conclusión del ex embajador de la República-para prepararse con armas y bagaje a la lucha puede enfrentarse con éxito al fascismo, «que no es un fenómeno efímero, sino la última etapa política por la cual ha de pasar el Estado capitalista en todos los países». El Socialista, 30 de octubre de 1933. 
El día 11 de noviembre, publicó El Socialista el manifiesto electoral, del partido, redactado por Prieto, aunque aparecía firmado por «la comisión electoral». Tras una extensa interpretación «heroica» de la historia de «la cooperación socialista en las luchas políticas de España», se ponderaba la obra social de los socialistas en el bienio. Se hacía hincapié en su oposición a la disolución de las Cortes, a la prematura convocatoria de las elecciones, a la inobservancia del artículo 75 de la Constitución y a la designación de Lerroux, «sin duda en premio a la criminal obstrucción parlamentaria, que realizó su minoría», como jamás nadie de ellos lo hiciera en los parlamentos monárquicos. El ataque mayor se reservaba contra las alianzas electorales de los radicales: «los más repugnantes contubernios electorales se han establecido entre el partido sedicente republicano que predomina hoy en el Gobierno y los más insolentes y desenfadados enemigos del régimen. El lerrouxismo, que tiene ya concertadas desvergonzadísimas alianzas electorales con monárquicos y reaccionarios de toda laya, aspira a encontrar dentro de las futuras Cortes su base de sustentación en los enemigos de la República».

Todo lo justifican -clamaba el tribuno bilbaíno metido a redactor de manifiestos- en el afán de combatir a los socialistas, «el más firme baluarte de la República, y la más sólida garantía contra cualquier intento de retroceso político. ¡Atrás, ni un paso! Ése debe ser nuestro lema». Seguros del apoyo de la mujer proletaria, que en estas elecciones estrenaba su voto, y fiados en el triunfo, si la República llegada a inaugurar «un sistema de coacciones tan repulsivas como las que deshonraron a la monarquía», el espíritu de victoria socialista les haría «saltar denodadamente sobre ellas». La nueva página triunfal iba a ser prólogo «a otras jornadas más decisivas para la victoria plena del proletariado, que sólo es posible con el adueñamiento total del Poder político por la clase obrera».

Ni Largo Caballero hubiera escrito mejor el último párrafo, tan «totalitario», típicamente «prietista».

\section{LA PRIMERA VUELTA Y SUS EFECTOS.}

Tampoco el día de las elecciones fue un día tranquilo en toda España. A la una de la madrugada del domingo día 19, le avisaron de Ponferrada al líder cedista que los socialistas acababan de dar muerte a un muchacho de la JAP (Juventudes de Acción Popular, integradas en la CEDA), cuando repartía candidaturas. El ministro Rico Avello envió, a petición de Gil Robles, a la guardia civil al lugar del crimen. Unas horas antes le habían comunicado la muerte de otro afiliado, «a consecuencia de una refriega con un grupo de extremistas» en Los Navalmorales (Toledo), así como los asesinatos del jefe de propaganda de la Derecha Regional Valenciana, también integrada en la CEDA, y de otro propagandista de cedista en Fuente Encarroz. Poco más tarde, a la hora de constituirse los colegios, 
caía, herido de muerte, un apoderado del mismo partido. Gil Robles da en cada caso el nombre y el apellido.

En Madrid, capital y provincia, en la jornada electoral menudearon las violencias y coacciones, según la misma fuente. Hubo incidentes serios en los barrios extremos y en algunos pueblos como Aranjuez, Chamartín de la Rosa, Ciempozuelos, El Escorial, Hortaleza, Villaverde..., pero, al parecer, sin muertos ni heridos graves ${ }^{71}$.

Tras la primera vuelta, de un total de 473 diputados a Cortes, fueron proclamados 378, y 95 quedaron por elegir. La gran mayoría de los elegidos pertenecían a las candidaturas agrarias o a las que llevaban el marchamo de Acción Popular o el del PRR de Lerroux. Las diversas derechas habían obtenido en la primera vuelta 169 escaños; los republicanos radicales, 78; diversos partidos de centro derecha (entre ellos, la Lliga Regionalista), 51; los republicanos de izquierda (con el peso mayor de la Esquerra Republicana), 34; los socialistas, 31, y otros grupos menores, 15.

La derecha, casi ausente en las elecciones legislativas de junio de 1931 tras la conmoción del cambio de régimen y los primeros movimientos anticlericales, había vuelto con fuerza a la vida pública, como lo venían anunciando en las Cortes desde hacía tiempo sus voceros principales. El electorado había virado a la derecha. Pero, como había advertido Azaña, la falta de entendimiento entre las diversas formaciones republicanas y entre éstas y el partido socialista hizo lo demás. Cosa parecida pensaba y escribía Prieto. Una coalición entre los partidos que gobernaron en los dos primeros Gobiernos provisionales les habría dado el triunfo en dos tercios de las circunscripciones, con la ley electoral recién reformada. En cambio, una coalición de todos los partidos que participaron en los últimos gobiernos azañistas sólo habría triunfado en la cuarta parte de las circunscripciones.

La política seguida por Azaña no tenía, pues, el favor del pueblo español en las postrimerías de 1933, como ya lo habían martilleado a diario sus adversarios políticos desde enero de ese año, y especialmente tras los la matanza de Casas Viejas, las elecciones municipales de abril y las del Tribunal de Garantías, en septiembre.

El ministro de Comunicaciones, Emilio Palomo, del PRRSI, trató en balde de gestionar una coalición republicanos-socialista en las circunscripciones obligadas a la segunda vuelta. Su compañero de gabinete, Juan Botella Asensi, ministro de Justicia, y representante del minúsculo IRS, propuso, en cuanto se conocieron los resultados del domingo 19, la anulación de las elecciones y dimitió al ser rechazada su antidemocrática propuesta $^{72}$. Otro ministro, el de Industria y Comercio, Félix Gordón Ordás,

${ }^{71}$ Gil Robles, J. M., No fue posible paz, op. cit. p. 101.

${ }^{72}$ Martínez Barrio sitúa el motivo de la dimisión de Botella, ministro de Justicia -sus- 
presidente del PRRS, quería la disolución de las Cortes antes de reunirse las mismas, y antes incluso de la segunda vuelta electoral, disparate al que se opusieron los presidentes de la República y del Gobierno ${ }^{73}$.

No fueron sólo los tres ministros. Nos cuenta el entonces presidente del Gobierno ${ }^{74}$ que, a los pocos días de las elecciones, Manuel Azaña le pidió en una carta que constituyera un ministerio con las fuerzas de izquierda para convocar nuevas elecciones, porque, según él, a causa de la división de los republicanos, la representación salida de las urnas reducía en dos tercios las verdadera voluntad general de los españoles, y eran «evidentes los peligros» que acechaban a la República. Terminaba su misiva con la amenazante pregunta de qué haría el presidente del Consejo, si todos los partidos republicanos retirasen sus ministros del Gobierno. Martínez Barrio le respondió que el resultado electoral no lo había discutido nadie, que la división de los republicanos era responsabilidad suya y que él asumiría todas las carteras de los ministros que pudieran abandonarlas y que nombraría los nuevos titulares. Fechada el 5 de diciembre, recibía Barrio otra carta, esta vez firmada por Manuel Azaña, Marcelino Domingo y Santiago Casares Quiroga, en la que venían a solicitar lo mismo, aludiendo a "consecuencias muy graves», en las que no querían verse comprometidos. Añadían que su opinión y su deseo lo compartían

tituido por el ministro de Instrucción Pública, Domingo Barnés- antes de las elecciones, debido a un duro enfrentamiento con el ministro de la Gobernación, Rico Avelllo, tras la fuga de Juan March de la prisión de Alcalá de Henares, el 4 de noviembre: los dos, abogados y masones, se achacaban mutuamente la responsabilidad política de lo sucedido, Martínez Barrio, D., Memorias, op. cit., p. 208.

73 Avilés Farré, J, La izquierda burguesa en la II República, op. cit., pp. 222-223. Cuando Botella, el ministro de Justicia radical-socialista de izquierda (IRRS) dimite el 29 de noviembre, denuncia -como lo recoge El Socialista de 1 de diciembre- que «las elecciones por inhibición lamentable de los órganos encargados de dirigirlas, han ofrecido los mayores ejemplos de de inmoralidad y de ilegalidad que jamás se han conocido, pues nunca como esta vez ha corrido el oro de las derechas, ni se han explotado más el fanatismo religioso, ni ha habido mayores amaños ni falsedades de actas...» La denuncia, demasiado tardía, de todo un ministro de Justicia, es asimismo demasiado vaga y demagógica. Botella, a quien el PRR le debía ciertos favores desde los primeros tiempos de la obstrucción parlamentaria con motivo de Casas Viejas, era un político extravagante, molesto incluso en su partido, PRRS, que fue el primero en abandonar para fundar otro minúsculo. La comisión ejecutiva del PSOE no aceptó su nombre para ser incluido en una candidatura conjunta republicano-socialista por Alicante para las elecciones legislativas de noviembre. Ver también la severa recriminación que hace Alcalá Zamora de la actitud de estos dos ministros, MARTínez BARRIO, D., Memorias, op. cit., p. 306.

${ }^{74}$ Martínez Barrio, D., Memorias, op. cit., p. 212, donde se transcriben los textos de las cartas. 
sus «organizaciones políticas, y algunas más, representadas o no en el Gobierno» ${ }^{75}$.

Entre la primera y la segunda vuelta, según nos hace saber Alcalá Zamora $^{76}$, le dijo un día Besteiro, riendo, que se preparase «para oír alguna locura muy grande». Y fue que Juan Negrín, ilustre fisiólogo de profesión, en veste de representante del grupo parlamentario socialista, le visitó para aconsejarle la formación de un Gobierno de izquierdas, con mandato de disolución de las Cortes, pero aplazada mientras se elaboraba una nueva ley electoral que asegurara el triunfo de los partidos de izquierda. En el ínterin, un decreto presidencial suspendería las sesiones parlamentarias y gobernaría el presidente de la República en colaboración con la Diputación permanente de las Constituyentes. ¡La «invención» de tamaño embrollo jurídico y dislate político lo atribuye don Niceto, no sé con qué razón, a la colaboración de Fernando de los Ríos, jurista que se hace interpretar por un fisiólogo, sin el intercambio correspondiente!

Como he apuntado antes, las corrientes más izquierdistas de los partidos republicanos ex gubernamentales, no estaban lejos de las actitudes extremas de algunos de sus dirigentes. Para ellos, como lo había proclamado a menudo Manuel Azaña, y lo defendía férreamente Largo Caballero, la República era obra y cosa de los republicanos, un coto cerrado de su propiedad, y cualquier intento de entrar en ese terreno vedado era un delito de lesa República ${ }^{77}$.

75 Alcalá Zamora habla exageradamente de «tres golpes de estado» en veinte días, aludiendo a las propuestas de Botella, Gordón y a esta carta de los tres ex-mandatarios republicanos, y con toda la ironía del mundo dice ignorar si figuraban en esa carta signos «de fraternidad masónica, pero el llamamiento tácito a lo solidario de esta relación se trasparentaba clarísimo». Memorias..., pp. 300-301. Pueden añadirse a esa triple presión la amenaza no velada de Largo Caballero, al final de su mitin del día 28 de noviembre, en el cine Europa, como los veremos en seguida, y la visita al presidente del diputado socialista Juan Negrín, vicepresidente del GPS.

76 Martínez Barrio, D., Memorias, op. cit., p. 301.

77 En la misma publicación, antes citada, de las juventudes de AR, el partido de Azaña (nota 85), se juzga el resultado de las elecciones de noviembre como «inicuo y falso», pero sin mostrar indicios ni prueba alguna al respecto, y se arremete contra «la famosa juridicidad, en cuyo nombre se yuguló todo el empuje revolucionario de abril del 31». Se juzgan igualmente esos momentos como de máxima responsabilidad para los dirigentes del republicanismo de izquierda; «si éstos -se añade-, ahítos de legalidad, desoyen en esta hora histórica el latir revolucionario del pueblo español, serán desbordados por el empuje arrollador de las Juventudes, que no están dispuestas a dejarse detener por ninguna especie de varones prudentes». El presidente de las Juventudes de Acción Republicana, y responsable de la revista, Antonio Ruiz Rey, abandonó el partido antes de la segunda vuelta, y fue constituida de inmediato otra junta directiva, presidida por Gerardo Saura, Avilés Farré, J, La izquierda burguesa en la II República, op. cit., p. 223. 
La comisión ejecutiva del PSOE se reunió el día 22 de noviembre, con las ausencias de Vidarte y Carrillo ${ }^{78}$. El presidente Caballero informó de las visitas recibidas de «algunos elementos republicanos» para tratar de las posibilidades de «formar una alianza electoral que evite en la segunda vuelta el triunfo de los candidatos de la derecha». Y por «acuerdo unánime» se publicó esta nota:

«La Comisión ejecutiva, ante las elecciones de la segunda vuelta que en varias provincias han de celebrarse el día 3 de Diciembre, recuerda a las organizaciones del Partido Socialista que, si alguna de ellas estimara procedente establecer alianzas electorales para esa segunda vuelta, deben consultar los respectivos casos a la Ejecutiva, de acuerdo con lo que, como norma general, decidió el Comité nacional. Pero, desde luego, la Comisión ejecutiva anticipa su criterio en absoluto contrario a autorizar coaliciones en las que hubieren de participar elementos del Partido Radical, considerando que la conducta de éste, al facilitar la entrega de la República a los reaccionarios mediante vergonzosos pactos con ellos, le hace indigno de cualquier solidaridad o contacto por parte de los socialistas».

El compañero De los Ríos, elegido ya (por la minoría) diputado por Granada), junto con María Lejárraga y Ramón Lamoneda, frente a la vencedora candidatura radical-cedista-agraria, informó sobre esa elección y la accidentada campaña, de la que hicimos mención, y el compañero Tomás, candidato sin suerte por la misma circunscripción a falta de 17 votos, amplió la información, a la vez que propuso dirigirse al comité de la UGT «para iniciar conversaciones sobre la acción futura a realizar por la Unión y el Partido». Se designó una comisión integrada por De Francisco, De los Ríos y Carrillo para que conjuntamente con la ejecutiva de la Unión trataran «sobre el particular» ${ }^{79}$.

La reunión de las dos comisiones designadas al efecto tuvo lugar el día 23 en el domicilio social de la $\mathrm{UGT}^{80}$. De los Ríos expuso el criterio de la dirección del partido sobre la necesidad de preparar «una acción común que

\footnotetext{
${ }^{78}$ AH-20-2, p. 102.
}

79 El resultado de las elecciones le produjo al diputado electo por Granada y vocal de la comisión ejecutiva una crisis muy grande, comparable -dirá él mismo más tarde-con la que sufrió «al salir de la Iglesia Católica». «Desilusión y asco», es lo que sintió al ver el fracaso del intento colectivo por «transformar el régimen económico por medio del organismo político, siendo por ello uno de los ensayos sociales que pudo haber dado más fruto». Zapatero, V., Fernando de los Ríos: Biografía intelectual, op. cit., p. 393. De los Ríos manifestó a sus compañeros su deseo de volver a la docencia. El 30 de diciembre dirigió una solicitud al ministerio de Instrucción Pública para que se le otorgase permiso para poder continuar explicando en su cátedra y conservar su actual situación académica, aunque estuviera en excedencia forzosa como diputado por Granada. Ibidem, p. 408.

${ }^{80}$ Largo Caballero, F., Escritos de la República: Notas históricas de la Guerra en España (1917-1940), op. cit., p. 42. 
impidiese la realización de los propósitos de los elementos fascistas». Preguntó Besteiro, con una larga intención política, con su habitual obsesión, si tal acción tendría por finalidad «la defensa de la República y la democracia burguesa». El «caballerista» Carrillo le contestó que la bandera debía ser «contra el fascismo y la dictadura burguesa», pero que los acontecimientos aconsejarían lo que convendría hacer. Besteiro y Trifón Gómez manifestaron entonces que, estando a punto de reunirse el comité nacional del sindicato, le darían cuenta de lo tratado y comunicarían a la dirección del partido las resoluciones que adoptara.

A la sesión del día 25 asisten todos los miembros de la dirección socialista $^{81}$. En primer lugar se da lectura a una carta de la Juventud Socialista de Madrid, en la cual se solicita que «el partido no acuda a una segunda vuelta electoral, por estimar que los apaños realizados por las fuerzas reaccionarias han de anular todos nuestros esfuerzos, y por lo tanto convendría abstenerse de ir a las elecciones. La ejecutiva les responde que laboren con más entusiasmo si cabe que en la primera vuelta electoral, por estimar que no hay impedimento alguno ante la contienda electoral y la labor que posteriormente exijan las circunstancias realizar para defender nuestras conquistas». Las dos últimas líneas, que aquí pueden parecer enigmáticas, responden a la exposición habitual del presidente del partido.

Se lee asimismo una carta de la UGT, en la que piden que se reúnan ambas ejecutivas para «tratar del problema electoral y del resultado obtenido en la primera vuelta», tema del comité nacional sindicalista reunido el día anterior. Como se ve, la organización sindical hermana se limita a tratar de algo muy concreto y no de una indeterminada «acción futura», tal como proponía la dirección política ${ }^{82}$.

Como en la sesión anterior se nombró ya una comisión «ad hoc», la comisión ejecutiva da paso sin más a la lectura por De los Ríos de una «información suscrita», que le ha sido entregada «por persona de su absoluta confianza», en la que se detallan «los deseos de los elementos reaccionarios de realizar actos violentos contra algunos camaradas significativos del Partido», pensando que podrían destruir a éste, una vez desaparecidos aquéllos. Dice, además, conocer por el mismo medio «el plan proyectado

${ }^{81}$ AH-20-2, p. 103.

${ }^{82}$ Desde el XVII Congreso de la UGT, en octubre de 1932, su presidente era Julián Besteiro, que lo había sido desde 1928 hasta febrero de 1931, y vicepresidente Andrés Saborit, que lo había sido también en ese mismo tracto de tiempo. Elegido en el mismo congreso secretario general Francisco Largo Caballero, casi por unanimidad, no aceptó el cargo, junto con otros vocales, también elegidos, como Pascual Tomás o Anastasio de Gracia, que formaban parte de la candidatura «caballerista», presidida por Manuel Cordero. Pero el congreso no le aceptó la renuncia y fungía, hasta febrero de 1934, de secretario general, como hemos visto, Trifón Gómez, elegido originariamente en la lista de Besteiro para el cargo de secretario adjunto. 
por algunos elementos militares, entre ellos clases de tropa, los cuales pretenden realizar un movimiento contra el Gobierno» ${ }^{83}$.

Largo Caballero, en una obra escrita varios años más tarde, transcribe una nota muy diferente, que podría ser, parcialmente al menos, la original, pero la sitúa en la reunión del 22 de noviembre, en la que De los Ríos afirma que esa «persona de su absoluta confianza es un guardia civil», quien le aconseja vigilar a los jefes de ese cuerpo - «todos fascistas, salvo contadas excepciones»-, que se reúnen con Gil Robles en los domicilios de Acción Popular, donde se da por segura la victoria en las elecciones y después por seguro un Gobierno republicano de acuerdo con Lerroux, que daría «el ataque a fondo a la República, con un fascismo o con una restauración (cosa que aún no habían logrado concretar)». Los políticos, objeto de acciones violentas serían Azaña, Domingo, Largo Caballero, Prieto, De los Ríos, Casares Quiroga y Bedía, éste último inspector de la guardia civil ${ }^{84}$.

Igualmente Prieto informaba en la misma sesión del día 25 que le había llamado urgentemente la ejecutiva de la UGT para informarle de que el Gobierno conocía «el proyectado plan de levantamiento de los militares y que a su vez se denunciaba la posible participación de algunos elementos socialistas en esta labor insurreccional».

«Todos y cada uno de los elementos de la Ejecutiva -se escribe como conclusión- demuestran con sus aclaraciones la falsedad de esta imputación, ya que nadie de los mismos ha tenido, ni tiene, compromiso con dicha clase de elementos».

Al final, el presidente añade una noticia insólita. Le visitaron «elementos de los llamados treintistas $»^{85}$, que se ofrecieron al partido para «realizar

${ }^{83}$ En algunos de sus discursos electorales Largo Caballero se hace cargo, entre irónico y escéptico, de ese rumor que hace correr, según dice, el Gobierno de Martínez Barrio. Por ejemplo, el 15 de noviembre, en el mitin de Salamanca: «Por eso un ministro inventó la infamia de un complot, por medio del cual se iban a levantar las clases y los soldados al mando de un nombre que no era ni Besteiro, ni Prieto ni de los Ríos (Risas)». No tenían siquiera el valor de decir que era él. Sólo lo dijeron vagamente. Si eso hubiera sido cierto, no lo hubiera rehuido, $\mathrm{y}$, en todo caso, un movimiento dirigido por él hubiera «sido para perfeccionar el régimen, convirtiéndolo en una República social». Y remata, artero, el orador: «Con tal declaración lo que se reconoce es que los soldados y la clase de tropa están al lado de los trabajadores: que el Gobierno no cuenta con la confianza del ejército y que tiene el temor de que los soldados y sargentos den señales de vida». Discurso en el teatro Bretón, de Salamanca, cit., p. 1952.

${ }^{84}$ Largo Caballero, F., Escritos de la República: Notas históricas de la Guerra en España (1917-1940), op. cit., p. 41.

${ }^{85}$ El «treintismo» (del número de firmantes del famoso Manifiesto de los Treinta) fue una corriente moderada y posibilista, sin dejar de ser revolucionaria, que defendía un período preparatorio, también de «elementos morales», antes de la revolución, dentro 
un movimiento de defensa en contra de los atropellos de la reacción, pero siempre controlados y dirigidos por la Unión General de Trabajadores y por el Partido». La ejecutiva «se da por enterada» de esta información, ya que «no es posible aceptar dicha colaboración sin previo acuerdo de ambas Comisiones ejecutivas y con elementos de responsabilidad que la soliciten oficialmente».

El mismo día 25, se celebró la reunión conjunta de los dos estados mayores $^{86}$. Por parte del PSOE asistieron todos sus miembros. Por parte de la UGT, todos menos José Castro. Besteiro, presidente de la Unión General, presenta el estado de la cuestión: su último comité nacional recomendó la reunión de las dos ejecutivas y posteriormente, si éstas lo consideraban conveniente, la de los dos comités nacionales. Trifón Gómez, el sustituto de Largo en la ejecutiva sindical y desde 1918 secretario general de Sindicato Nacional Ferroviario de UGT, sugiere crear un organismo de enlace de las dos direcciones para hacer frente en cualquier momento a cualquier situación. Largo Caballero, siempre conciso y directo, asevera que el compromiso «debe ser para realizar un movimiento revolucionario a fin de impedir el establecimiento de un régimen fascista». Besteiro, que no le pasa una a su contendiente ideológico, vuelve sobre la reunión anterior y recuerda que De los Ríos asintió a la pregunta que se le hizo de que la acción conjunta que llevar a cabo sería «para defender la República y la democracia». Pero el catedrático granadino, con cierto malhumor seguramente, replica que ni se contestó a la pregunta del ex presidente de las Cortes ni llegó a concretarse nada. Carrillo, en cambio, sí recuerda -y el acta sucinta parece darle la razón- lo que él dijo: que la acción no era ni para implantar el socialismo, lo que «habría de restarnos bastantes ayudas», ni para defender la democracia, «por si con ello se enfriaba el entusiasmo de nuestros camaradas, y que debe hablarse sólo de antifascismo, en lo que puede resumirse todo».

En este punto, T. Gómez entiende que lo que ahora conviene es «concretar cómo ha de realizarse la acción, pero nada más». El ex ministro De los Ríos desvía un tanto el tenso debate y pregunta si convendrá hace un manifiesto para fijar la postura de las dos ejecutivas y dar cuenta de la situación al presidente de la República, porque la parece muy grave que entregue el poder a quienes en sus declaraciones han dicho que «o las instituciones de la República se sometían a su voluntad o prescindirían

de la anarco-sindicalista Confederación Nacional del Trabajo, mayoritariamente dirigida por «faístas», más extremistas e inmediatistas, con un concepto «simplista, clásico, un tanto peliculero» -al decir del Manifiesto- de la revolución. Sus dirigentes más conocidos fueron Juan López, Agustín Gibanel, Ángel Pestaña o Juan Peiró.

${ }^{86}$ Largo Caballero, F., Escritos de la República: Notas históricas de la Guerra en España (1917-1940), op. cit., pp. 43-44. 
de ellas». Alusión clara a la frase, arriba comentada, de Gil Robles. Pero Largo, que no suele admitir desvíos en discusiones como ésta, fija de nuevo la posición que no es lo que plantea el compañero, sino «estudiar la forma de prevenirnos para hacer frente a los elementos reaccionarios»». Prieto, que ha permanecido callado hasta entonces, propone, recogiendo la sugerencia del comité nacional de la UGT, que los dos comités se reúnan para ver si tienen fuerza para realizar alguna acción. Él ve como características de la situación actual la depresión y la irritación, que no le satisfacen, y hacer una protesta contra las elecciones pasadas no resuelve absolutamente nada. Y se suma, aunque sin citarle, a la propuesta que al comienzo de la reunión hizo el secretario de la UGT: «nombrar una comisión mixta que se encargue de de examinar las circunstancias en todo instante».

Se acuerda formar esa comisión; también, a iniciativa de Cordero, publicar una nota de prensa, para cuya redacción se designa a Prieto, que, como se ve, hace, por esta vez, de puente, equilibrio y mediación, entre dos posiciones muy alejadas. Una vez leída y aprobada la nota, se levanta la sesión.

La nota, publicada en el órgano del partido al día siguiente, además de animar a los afiliados en la segunda vuelta a fortalecer la minoría socialista, «a la que ha de incumbir casi exclusivamente en el futuro Parlamento la defensa de los avances políticos y sociales obtenidos por medio de la República», decía así:

«Sometida a examen la situación política creada como resultado de la elecciones legislativas, hubo absoluta unanimidad de criterio, así al apreciar las consecuencias de ese resultado como al considerar imprescindible el vivir alerta ante el peligro de que el adueñamiento del poder por los elementos reaccionarios (bien lo ejerzan directamente o delegándolo en quienes les facilitaron el triunfo) les sirva para rebasar los cauces constitucionales en su público designio de anular toda la obra de la República, propósito contra el cual habrán de alzarse vigorosamente las organizaciones obreras».

Nota típicamente «prietista» por su vocabulario y sus conceptos, que en seguida reconocemos, con la doble alusión a los gilroblistas y a los radicales, y el interés por manifestar la unanimidad que no existía y por querer contentar a todos, al presidente del partido le debió de parecer, como lo rememora varios años después, expresión de falta de decisión y de varias contradicciones, como las de Prieto, «sin dejar por eso su desconfianza hacia la clase obrera organizada».

FLC aclara con su pícaro humor habitual las dos interpretaciones que habían de darse, en muchas ocasiones, a esta nota pretendidamente vaga, aprobada por todos, tenida como «documento oficial» para las 
futuras actuaciones de las dos organizaciones obreras ${ }^{87}$. La cuestión se planteaba así desde el primer momento, según el dirigente socialista: ¿el PSOE y la UGT habrían de «alzarse vigorosamente» cuando las derechas hubieran consumado su «designio», o cuando vieran claramente el «propósito» de realizarlo? El mismo presidente y sus amigos, Cabello, Carrillo, Tomás y De Francisco opinaban lo segundo; «otros» y la mayor parte de la dirección de la UGT, lo primero. La segunda cuestión era más espinosa todavía: ¿el movimiento «vigoroso» de las organizaciones obreras debía limitarse a defender «la obra de la República» o habría de aprovechar las circunstancias, si eran favorables, para imponer los postulados socialistas? La mayoría de la dirección política -se responde a sí mismo Caballero- defendían lo segundo; «otros» y la mayoría de la dirección sindicalista, lo primero; «los demás guardaban silencio». En ese pronombre «otros», Caballero incluye sin duda a Prieto y De los Ríos. Y añade por su cuenta, haciéndose portavoz de los trabajadores españoles del momento: «Los trabajadores españoles deseaban que el movimiento se iniciase con carácter antifascista, pero que, si era posible, debía transformarse dicho movimiento en socialista. De la República no habían sacado nada más que decepciones. ¿Para qué, si no, se organizaban las alianzas obreras?»

TITLE: The crash of the PSOE in 1933. From the Government to the Revolution (and II).

RESUMEN: Desde el discurso del ministro Largo Caballero en Ginebra, anterior al del cine Pardiñas y al de la Escuela de Verano (1933), la deriva política del PSOE mayoritario era clara. La salida forzosa del Gobierno aumentó la agresividad frente a la «República burguesa» y a la «democracia burguesa», con la ayuda de las Juventudes Socialistas $y$ del órgano del partido "El Socialista». Los discursos electorales del presidente del partido y las Actas de la comisión ejecutiva de éste son la mejor prueba. La triple derrota electoral de ese año no haría más que exacerbar el sentimiento de frustración. Sólo resistía aún, aunque por poco tiempo, la "facción» de Julián Besteiro, presidente de la UGT: un marxista «ortodoxo», opuesto a la dictadura del proletariado.

ABSTRACT: From the speech of Minister Largo Caballero in Geneva, prior to the one that took place in the Pardinas cinema and the one at the Summer School, (1933), the political leeway of the majority of the PSOE was clear. The forced exit of the Government increased the aggressiveness against the "Bourgeois Republic» and the "Bourgeois Democracy", with the help of the Socialist Youth Association and the official newspaper "El Socialista» ("The Socialist»). The election speeches of the head of the Party and the minutes of the Party-Board are the best evidence of it. That year, the triple election defeat only ag-

${ }^{87}$ Ibidem, pp. 45-46. 
gravated the feeling of frustration. The «fraction» of Julián Besteiro, president of the UGT (General Trade Union), an "orthodox» Marxist, opposed to the dictatorship of the proletariat, was the only one resisting, an just for a short time.

KEY WORDS: Socialist Party of Spain, Second Republic, Democracy, Revolution.

Recibido: 05.03.2012

Aceptado: 31.05.2012 